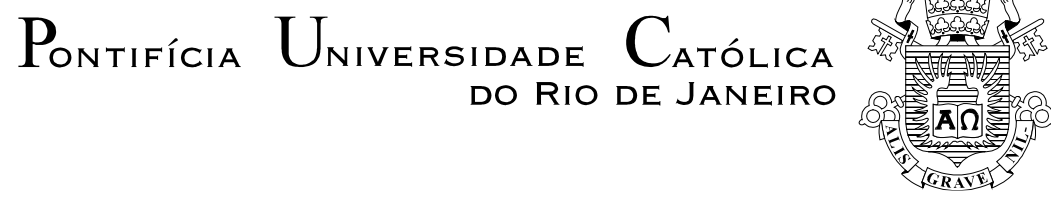

Roberta Goncalves Pereira Kehdi

Estado da arte de cuidar: apontamentos sobre estudos contemporâneos acerca da relação entre cuidado e família

Dissertação de Mestrado

Dissertação apresentada ao Programa de PósGraduação em Serviço Social da PUC-Rio como requisito parcial para obtenção do grau de Mestre em Serviço Social.

Orientador: Prof. Antonio Carlos de Oliveira

Rio de Janeiro

Julho 2017 


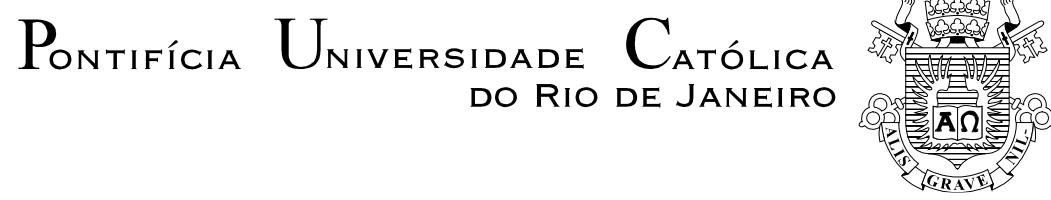

Roberta Goncalves Pereira Kehdi

\section{Estado da arte de cuidar: apontamentos sobre estudos contemporâneos acerca da relação entre cuidado e família}

Dissertação apresentada como requisito parcial para obtenção do grau de Mestre pelo Programa de Pós-Graduação em Serviço Social do Departamento de Serviço Social do Centro de Ciências Sociais da PUC-Rio. Aprovada pela Comissão Examinadora abaixo assinada.

Prof ${ }^{\circ}$ Antonio Carlos de Oliveira

Orientador

Departamento de Serviço Social - PUC-Rio

Prof ${ }^{a}$ Inez Terezinha Stampa

Departamento de Serviço Social - PUC-Rio

Profa Myriam Moraes Lins de Barros

UFRJ

Prof ${ }^{\text {a }}$ Mônica Herz

Vice-Decana de Pós-Graduação do

Centro de Ciências Sociais - PUC-Rio

Rio de Janeiro, 07 de julho de 2017. 
Todos os direitos reservados. É proibida a reprodução total ou parcial do trabalho sem autorização da universidade, do autor e do orientador.

\section{Roberta Gonçalves Pereira Kehdi}

Graduou-se em Psicologia pela Universidade Santa Úrsula em 2004. Especializou-se em Terapia Cognitivo Comportamental em 2006, e em Violência Doméstica pela Pontifícia Universidade Católica do Rio de Janeiro em 2010. Atualmente trabalha como professora na Escola Britânica do Rio de janeiro.

Ficha Catalográfica

Kehdi, Roberta Gonçalves Pereira

Estado da arte de cuidar: apontamentos sobre estudos contemporâneos acerca da relação entre cuidado e família / Roberta Gonçalves Pereira Kehdi; orientador: Antonio Carlos de Oliveira. 2017.

$81 \mathrm{f} . ; 30 \mathrm{~cm}$

Dissertação (mestrado) - Pontifícia Universidade Católica do Rio de Janeiro, Departamento de Serviço Social, 2017.

Inclui bibliografia.

1. Serviço social - Teses. 2. Famílias. 3. Cuidado. 4. História. 5. Interpretação de sentidos. I. Oliveira, Antonio Carlos de. II. Pontifícia Universidade Católica do Rio de Janeiro. Departamento de Serviço Social. III. Título. 


\section{Agradecimentos}

Aos meus pais pelo amor e cuidado. Obrigada por apoiarem minhas decisões e por estarem sempre ao meu lado, mostrando que com esforço e dedicação conseguimos alcançar nossas metas. Vocês fazem falta...

Ao meu companheiro de todas as horas, Pablo, pelo incentivo e palavras de consolo nos momentos complicados do processo.

Às minhas irmãs, Maura e Zaíra, por todo carinho, apoio e torcida. Por se fazerem presentes mesmo quando a distância insiste em parecer infinita.

Ao Programa de Pós-Graduação em Serviço Social da PUC-Rio pela confiança em aceitar-me em seu quadro de mestrandos bolsistas e a CAPES por fomentar minha bolsa de estudos.

Ao Professor Antonio Carlos de Oliveira pelas orientações que ajudaram a organizar minhas ideias. Obrigada pela disponibilidade, pelo respeito a meu tempo de produção do trabalho, pelas palavras motivadoras e por acreditar na minha capacidade para executar o projeto.

Às professoras Myriam Moraes Lins de Barros e Inez Terezinha Stampa pelas contribuições no exame de qualificação, que fizeram a pesquisa ganhar uma nova abordagem.

Aos colegas de turma do mestrado, os quais muito admiro pela competência, por participarem das alegrias e dificuldades desta caminhada. 


\section{Resumo}

Kehdi, Roberta Gonçalves Pereira; Oliveira, Antonio Carlos de. Estado da arte de cuidar: apontamentos sobre estudos contemporâneos acerca da relação entre cuidado e família. Rio de Janeiro, 2017, 81p. Dissertação de Mestrado - Departamento de Serviço Social, Pontifícia Universidade Católica do Rio de Janeiro.

Tendo em vista a reduzida produção acadêmica acerca do cuidado sob uma perspectiva epistemológica, a análise histórica da constituição da família brasileira e dos processos através dos quais o cuidado passa a fazer parte deste contexto revela-se fundamental para avançarmos na discussão acerca do cuidado familial. Neste contexto, realizamos uma pesquisa bibliográfica com o objetivo de identificar elementos que contribuam para a conceituação do cuidado em família a partir da produção brasileira contemporânea, analisando-os a partir do método de interpretação de sentidos, tal como proposto por Gomes. Os resultados permitiram observar elementos que repetidamente aparecem nos estudos realizados, articulando o papel protetor da família, suas formas de cuidar e as diferentes maneiras de definir a categoria cuidado e denotando a complexidade da questão e a necessidade de se produzir novas formas de olhar para o cuidado em família.

\section{Palavras-chave}

Famílias; Cuidado; História; Interpretação de sentidos. 


\section{Abstract}

Kehdi, Roberta Gonçalves Pereira; Oliveira, Antonio Carlos de (Advisor). State of the art of caring: notes on contemporary studies about the relationship between care and Family. Rio de Janeiro, 2017, 81 p. Dissertação de Mestrado - Departamento de Serviço Social, Pontifícia Universidade Católica do Rio de Janeiro.

Considering the limited academic production of care from an epistemological perspective, the historical analysis of the Brazilian family's constitution and the processes through which care becomes part of this context is crucial to launch the discussion about family care. In this context, we carried out a bibliographical research with the objective of identifying elements that contribute to the conception of family care from Brazilian contemporary production, analysing them from the method of interpretation of meanings, as proposed by Gomes. The results allowed us to observe elements that repeatedly appear in the studies carried out, articulating the protective role of the family, their ways of caring and the different ways of defining the care category and denoting the complexity of the issue and the need to produce new ways of looking at the Family care.

\section{Keywords}

Families; Care; History; Interpretation of meanings. 


\section{Sumário}

1. Introdução 8

2. Famílias: construção histórica das famílias 20 brasileiras

2.1. Pensando as famílias no Brasil: conceitos, 20 características e transformações

2.2. Roda dos expostos e a lógica Médico- higienista 30

2.3. Bases fundadoras das relações de gênero 34

2.4. Proteção Social X Cuidado 43

3. Cuidado: o que é afinal? 48

3.1. A gênese do Cuidado 48

3.2. Elementos que podem contribuir para a definição de 53 cuidado

3.3. Cuidar: uma questão de gênero? 56

3.4. Gênero, geração e classes sociais 70

4. Considerações Finais $\quad 74$

5. Referências bibliográficas 76 


\section{1 \\ Introdução}

O presente estudo discute a relação entre família e cuidado, pois sabe-se que ambas categorias estão intimamente relacionadas, porém o que muitas vezes se constata através da leitura de material a respeito do assunto, é a dificuldade de entender as diversas maneiras de significar cuidado. A ideia partiu, portanto, da necessidade de sistematizar os estudos já realizados, a fim de analisarmos as diversas conceituações existentes. O estudo teve como foco as famílias brasileiras no período do Brasil- Colônia até os dias atuais.

Para atingirmos este objetivo, fizemos uma minuciosa revisão dos autores que abordaram o conceito ao longo do período histórico proposto, relacionando-o com a realidade das famílias brasileiras contemporâneas. Faz-se relevante mencionarmos que, apesar de esta pesquisa se propor a abordar o cuidado em família no contexto brasileiro contemporâneo, acreditamos ser relevante citar alguns autores não pertencentes a este contexto, dada a frequência com que são mencionados em estudos brasileiros sobre infância, família e cuidados parentais. Motivo pelo qual citaremos estudiosos de outras nacionalidades e fatos importantes ocorridos ao redor do mundo.

Desta maneira, estudando a relação entre as duas categorias, Cuidado e Família, identificamos elementos que devem compor a definição de cuidado para avançar na discussão em torno do cuidado familial.

A motivação para este trabalho adveio da necessidade de ampliar e complementar estudos anteriores, pois durante o curso de Psicologia, os assuntos relacionados à violência sempre geraram bastante interesse, tanto que no trabalho final discuti os aspectos psico-políticos da tortura durante o período do regime militar no Brasil. Após completar a faculdade, devido ao grande número de crianças que atendia em consultório, especialmente os casos de violência doméstica, houve necessidade de aprofundar o conhecimento ligado às relações familiares para que o trabalho fosse mais consciente, efetivo e envolvesse a família como um todo. Especializei-me em violência doméstica, realizando estudo da ocorrência de 
suicídio de crianças e adolescentes quando estes sofriam violência sexual intrafamiliar.

No decorrer do curso de Mestrado estudamos o contraponto da violência, para isso realizamos pesquisa aprofundada a fim de perceber de que maneira as famílias brasileiras foram se construindo ao longo da história e sua implicação com o cuidado. Esta ideia surgiu a partir da percepção da relevância do tema cuidado em família e o interesse que vem suscitando em estudiosos de diferentes áreas do conhecimento ao longo dos anos devido à sua complexidade e múltiplas abordagens.

Apesar de existirem diversos estudos abordando o cuidado em família, como por exemplo, o realizado por Mioto (1998) em que aborda a família como campo de proteção social reconhecendo suas dimensões simbólica e múltipla, tendo como tarefa primordial o cuidado de seus membros; ou aquele realizado por Araújo e Scalon (2007), em que tratam do tema cuidado em família sob a perspectiva de gênero, enfatizando as diferentes maneiras de cuidar entre homens e mulheres. Observamos que há lacunas quanto à definição mais precisa do que seja cuidado, pois o que temos são pesquisas mais voltadas a descrições da prática de cuidar em lugar de deter-se à uma análise mais estritamente conceitual.

Acreditamos ser importante relatar um pouco da trajetória percorrida até chegarmos ao recorte pelo qual optamos.

Quando começamos a busca por material que abordasse o tema cuidado, verificamos que a grande maioria dos textos citava a noção elaborada pelo filósofo Martin Heidegger (1889-1976) ${ }^{1}$ e, por isso, acreditamos ser relevante estudá-lo para entender como estudiosos estavam abordando este assunto. Vimos que, para

\footnotetext{
${ }^{1}$ Transcrevemos a fábula criada por Higino (Ia.C. e I d.C.) e utilizada por Heidegger para refletir a respeito do cuidado e sua origem: "Certo dia, ao atravessar um rio, Cuidado viu um pedaço de barro. Logo teve uma ideia inspirada. Tomou um pouco de barro e começou a dar-lhe forma. Enquanto contemplava o que havia feito, apareceu Júpiter. Cuidado pediu-lhe que soprasse espírito nele. O que Júpiter fez de bom grado. Quando, porém Cuidado quis dar um nome à criatura que havia moldado, Júpiter o proibiu. Exigiu que fosse imposto o seu nome. Enquanto Júpiter e o Cuidado discutiam, surgiu, de repente, a Terra. Quis também ela conferir o seu nome à criatura, pois fora feita de barro, material do corpo da terra. Originou-se então uma discussão generalizada. De comum acordo pediram a Saturno que funcionasse como árbitro. Este tomou a seguinte decisão que pareceu justa: "Você, Júpiter, deu-lhe o espírito; receberá, pois, de volta este espírito por ocasião da morte dessa criatura. Você, Terra, deu-lhe o corpo; receberá, portanto, também de volta o seu corpo quando essa criatura morrer. Mas como você, Cuidado, foi quem, por primeiro, moldou a criatura, ficará sob seus cuidados enquanto ela viver. E uma vez que entre vocês há acalorada discussão acerca do nome, decido eu: esta criatura será chamada Homem, isto é, feita de húmus, que significa terra fértil".
} 
Heidegger, nós não somente tomamos cuidado, nós somos cuidado, ou seja, devemos entendê-lo em um sentido existencial e parte da essência do ser humano. O que significa afirmar que cuidado é o homem, sem cuidado não existe homem, ele possui uma dimensão ontológica. Acrescenta ainda que o fenômeno não possui uma estrutura simples, do mesmo modo como o sentido de ser não é uma ideia simples, tampouco o é o conceito de existência, ao qual está intimamente relacionado.

Estudamos também Leonardo Boff (2011), filósofo existencial e seguidor do pensamento de Heidegger. Ele afirma que

Se não receber cuidado desde o nascimento até a morte, o ser humano desestruturase, definha, perde o sentido e morre. Se ao largo da vida, não fizer com cuidado tudo o que empreender, acabará por prejudicar a si mesmo e por destruir o que estiver à sua volta. (Boff, 2011, p.34).

Para Boff, o ser humano é entendido como um ser que dedica atenção, interesse e preocupação para com o outro. Segundo ele, "cuidado implica um modode-ser mediante o qual a pessoa sai de si e se centra no outro com desvelo e solicitude" (Boff, 2005, p.29). Há dois modos de ser-no-mundo: o trabalho e o cuidado. Na lógica do trabalho, o objetivo é "situar-se sobre as coisas para dominálas e colocá-las a serviço dos interesses pessoais e coletivos" (p.31). Em outras palavras, o homem é a peça principal e tudo o mais deve girar a seu redor e satisfazer as suas vontades. A relação é de sujeito-objeto. Pelo cuidado, a relação é de sujeitosujeito, significando convivência e troca, "uma forma de ser-no-mundo e, a partir daí, de relacionar-se com as demais coisas... Cuidar das coisas implica ter intimidade com elas, senti-las dentro, acolhê-las, respeitá-las, dar-lhes sossego e repouso. Cuidar é entrar em sintonia com as coisas" (Boff, 2005, p. 31).

Por este viés percebemos que cuidado implica preocupação com o outro, sair de si e centrar-se na outra pessoa, é através das relações que o ser humano irá construindo a si próprio.

Sob o olhar deste autor, o cuidado como forma de ser-no-mundo seria a solução para alguns problemas que afetam nossa sociedade, como por exemplo o descaso diante das necessidades de famílias pobres. Transcrevendo suas palavras, "Este é o modo-de-ser que resgata nossa humanidade mais essencial, cuja força pode servir de plataforma para um novo ensaio civilizatório” (p.34). 
Entretanto, o cuidado não é acolhido por todos de maneira unívoca; há os que o assumem de forma equilibrada e outros que o assumem de maneira patológica. Boff (2011) identifica três preocupantes patologias do cuidado: 1- a negação do cuidado essencial; 2- o cuidado em seu excesso: a obsessão; e 3- o cuidado em sua carência: o descuido. Para Boff (2011), a negação do cuidado resulta em um processo de desumanização e embrutecimento das relações se, quando isso ocorre, o ser humano se entrega ao mau trato das pessoas, da casa, da coisa pública e de si mesmo. $\mathrm{O}$ cuidado em seu excesso significa que a pessoa se torna obsessiva para cuidar de tudo e dos outros, e esta maneira de entender o cuidado é patológica porque o ser humano não pode ser só sua essência; o excesso de cuidado paralisa e prejudica a espontaneidade de quem o recebe. Por outro lado, o cuidado em sua carência também é patológico, pois não é saudável deixar as pessoas e coisas malcuidadas. Desta forma, o cuidado ideal é o ponto de equilíbrio entre a obsessão e o descuido; é o cuidado que não convive nem com o excesso e nem com a carência. Levando em consideração as reflexões de Boff (2011), pode-se afirmar que o cuidado sempre existiu na relação entre os seres humanos, mas que está sendo ameaçado pela atual tendência ao individualismo e falta de solidariedade.

Ao defender que a essência da humanidade se encontra basicamente no cuidado, Boff (2011) revela sua preocupação com a sociedade contemporânea, que vem ameaçando a vida humana ao criar a solidão entre as pessoas. $\mathrm{O}$ cuidado encontra-se cada vez mais distante nesta sociedade de caráter virtual, que comporta o encapsulamento sobre si mesma, o descarte das pessoas concretas e a falta de contato com o outro. Como solução do problema da falta de cuidado, denominada pelo autor de descuido, este defende o princípio inspirador de um novo paradigma de convivência, no sentido amplo de respeito e preservação de tudo o que existe na terra.

Seguindo o pensamento de Boff, podemos dizer que atualmente a sociedade enfrenta uma crise civilizacional agravada pela hegemonia do individualismo, o que significa afirmar que estamos contrariando a própria essência do ser humano. Além disso, o autor trata o cuidado de uma forma macro, referindo-se ao cuidado com o planeta, o meio ambiente e a sociedade sustentável e, atribui também uma dimensão micro, relacionada ao cuidado com o outro.

Outro filósofo que se ocupou do conceito de cuidado foi Michel Foucault, entretanto sob a perspectiva do cuidado de si. Este autor afirma que é necessário 
primeiro o cuidado consigo mesmo para que possamos exercê-lo com o outro, porém ressalta que o cuidado de si não é para ser visto como algo individualista ou egoísta, mas no contexto amplo das práticas sociais, "não se deve fazer passar o cuidado dos outros na frente do cuidado de si; o cuidado de si vem eticamente em primeiro lugar, na medida em que a relação consigo mesmo é ontologicamente primária" (Foucault, 2006, p. 271). E complementa, "é um princípio válido para todos, todo o tempo e durante toda a vida" (Foucault, 1985, p. 53).

Depois de algumas buscas pelo campo da Filosofia, percebemos que, apesar de estas pesquisas serem de grande importância para as pessoas que pretendem se aprofundar no estudo do cuidado, não contribuem decisivamente para sua conceituação. Deste modo, fomos buscar no campo da Psicologia alguns autores que pudessem acrescentar ao estudo que estamos realizando.

Um autor que trabalha o cuidado sob a perspectiva do cuidado com o outro, é o pediatra e psicanalista inglês, Donald Winnicott (1896-1971). Ele realizou profundo estudo sobre a importância e os efeitos do cuidado materno sobre a criança e, por esta razão, resolvemos pesquisá-lo mais a fundo. Segundo o estudioso, todo ser humano teria potencial inato para amadurecer e se desenvolver, porém esta tendência não garante que isto de fato ocorrerá. Assim sendo, apenas com um ambiente facilitador, que atenda às necessidades da criança é que a mesma poderá se desenvolver. No início, este ambiente é representado pela mãe suficientemente boa. É importante ressaltar que estes cuidados dependem da necessidade de cada criança, pois cada ser humano responderá ao ambiente de forma diferente, apresentando, a cada momento, condições, potencialidades e dificuldades diversas. Segundo Winnicott (1971), a mãe suficientemente boa (não necessariamente a própria mãe do bebê) é aquela que efetua uma adaptação ativa às necessidades do bebê, uma adaptação que diminui gradativamente, segundo a capacidade deste em lidar com o fracasso da adaptação e em tolerar os resultados da frustração.

Um conceito desenvolvido por Winnicott (1960) é o de holding, que de maneira sucinta seria a capacidade da mãe em se identificar com seu filho permitindo satisfazer suas necessidades. As mães que possuem esta capacidade para prover o cuidado suficiente, teriam sido cuidadas elas mesmas quando crianças, de forma que conhecem a natureza essencial do ato de cuidar. Mães que não possuem esta capacidade, não podem prover o cuidado suficiente por mera instrução. Holding inclui especialmente o segurar a criança, que é uma forma de amor e, 
talvez, o único modo que uma mãe pode demonstrar seu amor pelo filho (Winnicott, 1960$, p. 592 $)^{2}$. O autor ainda acrescenta que é preciso que a mãe se identifique com seu filho, a fim de que saiba o que sente e possa suprir suas necessidades; esta identificação é essencial para a adaptação da criança.

Para Winnicott, o papel da família é o de, fundamentalmente, promover o atendimento das necessidades físicas, sociais e afetivas de seus membros. Desta forma, "temos, pois, duas coisas distintas: as tendências inatas do bebê e o lar que você lhe proporciona. A vida consiste na interação dessas duas coisas" (Winnicott, 1999, p. 144)

As necessidades físicas referem-se à sobrevivência: abrigo, segurança e alimento. Já as de natureza social e afetiva, dizem respeito ao desenvolvimento emocional e cognitivo, constituindo-se a identidade, a individualidade, o sentimento de pertencimento, amparo e proteção dos sujeitos a ela pertencentes.

Neste contexto, cabem algumas considerações sobre o ambiente, que influencia diretamente as configurações familiares. A este respeito, podemos falar em famílias saudáveis, ou funcionais, e famílias disfuncionais. As famílias saudáveis ou funcionais, segundo Macedo (1994, p.186), caracterizam-se por um "ambiente acolhedor, continente, podendo as relações entre seus membros serem caracterizadas como amorosas, carinhosas e leais", e as disfuncionais, ainda conforme a mesma autora, propiciam a convivência em um "ambiente disjuntivo e os relacionamentos assumem características de ódio, culpa, vingança".

Nas primeiras, o crescimento de seus membros é promovido, nas segundas, bloqueado. Trata-se, então, da qualidade do ambiente e das vivências nele realizadas, aliada aos processos internos do sujeito em desenvolvimento. Como afirma Winnicott (1999, p.148) “o suprimento ambiental ou fornece uma oportunidade para que ocorra o processo interno de crescimento, ou então impede que tal aconteça”.

Em relação a este ambiente, questões como a comunicação, as regras e limites, a própria organização da rotina, as relações de poder, são aspectos muito

\footnotetext{
${ }^{2}$ Livre tradução do original: It should be noted that mothers who have it in them to provide good enough care can be enabled to do better by being cared for themselves in a way that acknowledges the essential nature of their task. Mothers who do not have it in them to provide good enough care cannot be made good enough by mere instruction. Holding includes especially the physical holding of the infant, which is a form of loving. It is perhaps the only way in which a mother can show the infant her love of it.
} 
importantes na constituição e manutenção das famílias e devem ser levados em consideração em qualquer análise que se faça, seja qual for o objetivo em questão, visto que estão todos inter-relacionados. Como afirma Zimerman (1999, p.104), "uma família bem estruturada requer algumas condições básicas, como é a necessidade de que haja uma hierarquia na distribuição de papéis, lugares, posições e atribuições, com a manutenção de um clima de liberdade e de respeito recíproco entre os membros".

Além disso, essas são questões que contribuem de forma decisiva na formação dos indivíduos, como nos elucida Winnicott $(1989$, p.103) a respeito da família "cuja estrutura se relaciona com a estrutura da personalidade do indivíduo". Disto podemos inferir o quanto é importante proporcionar à criança um ambiente saudável, propício ao pleno desenvolvimento de suas potencialidades, que a proteja e desperte o prazer de viver, caso contrário, pode ocorrer um "fracasso do suprimento ambiental" (Winnicott, 1999, p.149), gerando danos ao saudável crescimento.

Todavia, apesar de sabermos da relevância de um lar saudavelmente constituído, não podemos deixar de mencionar que não há lar perfeito, nem família ideal. Todas as pessoas têm problemas e todas as crianças, em algum momento de seu desenvolvimento, revelam algum sintoma, alguma pista de que algo não vai perfeitamente bem. Conforme Winnicott (1982, p.142), "mesmo o mais carinhoso e compreensivo ambiente de vida familiar não pode alterar o fato de que o desenvolvimento humano vulgar é árduo e, na verdade, um lar perfeitamente adaptativo seria difícil de perdurar, visto que não haveria qualquer alívio através de uma cólera justificada".

Deste modo, cada família busca oferecer o melhor possível ao desenvolvimento de seus membros, da forma que considera mais adequada e possível. O que será feito com o que é oferecido depende, em grande parte, do próprio sujeito, daquilo que é capaz de conseguir naquele momento, frente aquela experiência singular. Neste jogo de interações e relações múltiplas desenvolvem-se os sujeitos que criarão sua própria história.

Ainda no campo da Psicologia, examinamos o estudo do apego ou vinculação, realizado pelo britânico John Bowlby (1990), esta investigação começou por uma pesquisa a respeito das origens do desenvolvimento psicopatológico, tanto na infância como na idade adulta. A teoria afirma a existência de um sistema 
comportamental que regula os comportamentos de busca de proximidade e a manutenção de contato da criança com indivíduos específicos que transmitam segurança para a mesma.

Bowlby (1990) acredita que o vínculo da criança com sua mãe (entenda-se mãe como a pessoa que representa a figura de apego, que pode ser o pai, tia, irmão) não é movido pela busca de satisfação do seu desejo, como acreditavam alguns teóricos, mas é o resultado da atividade de sistemas que buscam proximidade. Tal ideia é confirmada, segundo Abreu (2005) quando observamos "uma criança em seu segundo ano de vida, quando se locomove para alcançar a mãe na presença de circunstâncias ameaçadoras" (Abreu, 2005, p.52). Esta atitude é denominada comportamento de vinculação e visa à restituição da segurança pessoal.

Portanto, Bowlby entende por comportamento de vinculação:

Qualquer forma de comportamento que faça com que uma pessoa alcance ou conserve a proximidade de outro indivíduo diferenciado e preferido, isto é, uma consequência de um sistema básico regulador de grande importância biológica para a sobrevivência pessoal. (Bowlby, 1990, p.56).

Para o autor, há evidências de que os seres humanos serão capazes de se desenvolver quando estiverem seguros de que existem pessoas ao seu redor prontas a ajudar caso surjam dificuldades.

É interessante notarmos que John Bowlby não utiliza a denominação cuidado, porém sua definição de vinculação abarca diversas formas de entender cuidado pelo viés dos autores já citados.

Após algumas investidas na área da Psicologia, entretanto, verificamos também que estudar a ausência do cuidado e as consequências que esta poderia gerar, não nos levaria ao nosso objetivo: identificar elementos que pudessem contribuir para a conceituação de cuidado e, mais uma vez optamos por mudar a direção da pesquisa.

Observamos que dentro do contexto das Ciências da Saúde há diversos estudos relacionados ao cuidado. Talvez esta seja a área que mais se dedicou a pesquisar sobre o tema e, então, decidimos explorar o material que existia a respeito.

Segundo o pensamento da professora doutora em Ciências da Saúde, Damaris Gomes Maranhão, em que afirma ser o cuidado uma atividade relacional originada a partir dos desejos de quem cuida, atribuindo necessidades ao objeto do seu 
cuidado de acordo com o sentido que o cuidado tem para ele/a, em conformidade, muitas vezes, com seu contexto sociocultural (Maranhão, 2000, p.126). Esta autora acredita que é preciso uma interação entre quem cuida e quem é cuidado, ou seja, a criação de vínculos.

Todavia, após estudar alguns textos que seguiam esta linha, logo percebemos que este campo trata o cuidado como prática e, desta maneira, não contribuiria para o estudo a que nos propomos, pois o que almejamos é compreender o cuidado como conceito. Assim, a partir desta constatação, focaremos a pesquisa em autores das Ciências Sociais, como Antropologia, História e Sociologia porque acreditamos que dentro desta perspectiva atingiremos o objetivo a que nos propusemos, tratando o conceito sob uma dimensão epistemológica.

Como podemos perceber, o desafio deste trabalho é encontrar material que seja relevante ao tema e sirva para que consigamos uma base bem estruturada a fim de discutirmos e analisarmos o papel protetor da família, suas formas de cuidar e as diferentes maneiras de definir a categoria cuidado. Acreditamos, assim, que com este exercício de teorização, possamos contribuir para um maior conhecimento desta dinâmica.

Com o advento da alta conectividade e o acesso quase irrestrito a bases oficiais nacionais e internacionais de conhecimento permitidos pela internet moderna, a delimitação do recorte amostral do trabalho se torna parte essencial da pesquisa bibliográfica, pois existem infinitas possibilidades de acesso a bases científicas eletrônicas. Além disso, acreditamos ser relevante o levantamento de material impresso, com utilização de livros a respeito do assunto abordado pelo presente estudo, a fim de que buscássemos atingir o objetivo visado. Em primeiro lugar, realizamos revisão de literatura para refletirmos acerca dos estudos já realizados, observando que aspectos poderiam ser aprofundados, questões já abordadas por outros autores, refletindo as diversas maneiras de abordar o assunto e levantando contradições sobre o mesmo. A principal vantagem deste tipo de trabalho é o fato de permitir investigar uma enorme variedade de fenômenos através da pesquisa de materiais já elaborados, possibilitando o aprofundamento de pensamentos e contraposição de diferentes ideias.

Outro fator decisivo que nos levou a optar pela pesquisa bibliográfica foi o de que ele permite acrescentar a dimensão do tempo à compreensão do social. A análise documental favorece a observação do processo de maturação, modificações 
e permanências de indivíduos, grupos, conceitos, conhecimentos, comportamentos, mentalidades, práticas, entre outros.

Desta maneira, este trabalho optou por deter sua pesquisa bibliográfica nas bases eletrônicas de informação e livros.

O processo de pesquisa bibliográfica trabalhou com duas linhas de busca de referencial teórico, a primeira consistiu na busca de autores específicos definidos a partir de pesquisa bibliográfica preliminar em periódicos de ampla circulação, como revistas técnicas, e/ou na comunicação pessoal dentro do espaço acadêmico; e a segunda pela busca aleatória, com base em palavras-chave, em motores de busca eletrônica de base científicas, ou não, de amplo reconhecimento e popularidade. Como principais motores de busca utilizados citam-se: o motor de busca geral Google e os motores de busca científica, em ordem de prioridade de uso, Periódicos Capes, base oficial gerenciada pelo órgão nacional de fomento à pesquisa científica Capes, e a base Google Acadêmico, agregador de busca de trabalhos científicos, criado e gerenciado pelo motor de busca geral Google.

Depois de busca preliminar, percebemos que seria necessário delimitar o período histórico e definirmos um espaço amostral limitado para amalgamarmos o material encontrado e dialogar com os autores cujo recorte temporal fosse o mesmo. Assim, traçamos um panorama histórico: estudamos o período do Brasil colônia até a contemporaneidade. A escolha por este período deveu- se à riqueza e contribuição que daria ao estudo.

Após a identificação de autores relevantes pela pesquisa preliminar, a primeira linha de busca seguiu com uma procura aleatória associando o nome do autor encontrado a outro recurso de filtro comum às bases, que é a seleção de artigos por identificação de autor. Além disso, para a definição das palavras-chave ou descritores de pesquisa optou-se pelo uso de palavras existentes nos artigos encontrados e em suas referências.

A segunda linha de pesquisa bibliográfica eletrônica teve um grau de liberdade um pouco superior. Definiu-se apenas o filtro para palavras-chave típicas, separadamente e/ou em conjunto, da relação família- cuidado, tais como: famílias, história, cuidado, epistemologia, dentre outras.

A lista de palavras-chave da segunda linha de trabalho foi uma lista nãoexaustiva, que a cada nova busca poderia ter palavras adicionadas, retiradas e/ou reassociadas; se a busca se mostrasse com um retorno muito alto, mais de 500 
ocorrências. Além disso, dada a tendência de retorno muito alto de resultados de pesquisa em banco de dados eletrônicos (geralmente 26,700 ocorrências, sendo a grande maioria composta por artigos publicados em revistas especializadas), foi utilizada ainda a ferramenta, também comum a todos os motores de busca, de ordenação dos resultados por relevância, que possui parâmetros internos ao motor que relacionam informações como número de acessos, citação ao link, ao título, ao autor do artigo ou ainda pelo número de acessos recentes ao link.

Levando em conta ainda que a maior parte das bases científicas tem como língua obrigatória de publicação o inglês, considerada a principal língua de comunicação internacional, concentramos a busca na base de dados também de palavras-chave em inglês tendo como ponto de partida a tradução das palavras citadas anteriormente, sendo, portanto, pesquisadas palavras-chave como: families, history, care, epistemology, dentre outras. Deste modo, conseguimos chegar a 100 ocorrências, possibilitando seguir para a próxima etapa da pesquisa de maneira mais direcionada ao objetivo do estudo.

Após a fase de levantamento da bibliografia existente a respeito do assunto, os textos foram separados por categorias e analisados através de leituras exploratórias, seletivas e interpretativas. Os resultados foram, então, organizados e trabalhados visando uma reflexão sobre elementos que podem contribuir para a definição de cuidado em família.

Desta maneira, foi possível um diálogo entre autores das mais variadas áreas de conhecimento e uma análise crítica do material já existente, complexificando a questão e produzindo novas formas de olhar para o cuidado em família. A riqueza de informações que deles podemos extrair e resgatar justifica o seu uso em várias áreas das Ciências Humanas e Sociais porque possibilita ampliar o entendimento de objetos cuja compreensão necessita de contextualização histórica e sociocultural.

Buscaremos refletir a respeito de algumas questões: como o cuidado aparece ao longo da história? Quais as características desta categoria para diferentes estudiosos? Como pensar a família? De que maneira a família se tornou espaço de cuidado?

Assim, no decorrer do primeiro capítulo pensaremos as famílias brasileiras, realizando um estudo da construção histórica da colônia à modernidade. Discutiremos os conceitos e transformações pelas quais as famílias passaram para entendermos os contextos influenciadores dos comportamentos atuais. $\mathrm{O}$ segundo 
capítulo abordará a construção histórica e social do Cuidado, considerando as produções a respeito do tema, porém concentrando- se em sua dimensão epistemológica. No último capítulo, trataremos o cuidado dentro do âmbito familiar, considerando a complexidade dos contextos existentes e relacionando três categorias importantes para o estudo: gênero, geração e classes sociais. 


\section{2 \\ Famílias: construção histórica das famílias brasileiras}

\section{1. Pensando as famílias no Brasil: conceitos, características e transformações}

A eterna mudança das sociedades humanas e de seu reajuste a novas condições tem sido o enredo principal da História, buscaremos expor algumas teorias acerca do estudo de família no Brasil a fim de compreender sua gestação e transformação ao longo da história brasileira.

Segundo concebe Morgado (2001), família é uma instituição que se modifica em consonância com as transformações históricas e que adquire particularidades em diferentes sociedades. A autora cita Bruschini (1993) para propor uma ruptura da concepção de naturalidade das organizações familiares, percebendo-a como criação humana mutável. Seguindo esta maneira de entender a família, Oliveira (2011) afirma que a sociedade percorreu um caminho histórico para chegar às bases da estrutura de família que predomina nos dias de hoje. Para o autor, houve um período inicial em que o casamento endogâmico era permitido, passando para um segundo período caracterizado por restrições a esse tipo de união, em princípio por interesses econômicos, até chegar à estrutura de família monogâmica patriarcal, cuja prevalência da dominação do gênero masculino sobre o feminino ainda é bastante evidente em nossa sociedade. O patriarcalismo, evidenciado pela identificação do masculino como referência social e pela autoridade do homem sobre a mulher e filhos no âmbito familiar, é uma das estruturas sobre as quais se assentam as sociedades contemporâneas (Saraiva, 1998). Devido à forte influência da estrutura patriarcal nas relações familiares atuais, consideramos importante sua contextualização histórica.

Deste modo, ao examinarmos a historiografia voltada para o estudo da família no Brasil, percebemos que a pesquisa é relativamente recente. Somente a partir das primeiras décadas do século XX serão iniciados os primeiros estudos, que, de um lado, tendem a afirmar que a família pode ser considerada a instituição social 
fundamental, da qual dependem todas as demais e, de outro, podem se vincular a dois posicionamentos conceituais específicos, que retomam três modelos básicos de família - a patriarcal, a nuclear e a atual. São eles: um primeiro, que se projeta a partir do modelo da família patriarcal como um modelo histórico da família brasileira; e um segundo, em que este modelo é revisto. Outros autores somente destacam a importância da família como instituição. Da Matta (1987), por exemplo, conclui que a família no Brasil- Colônia era considerada uma instituição indispensável para a vida social, afirmando que a pessoa que não fizesse parte de um círculo familiar praticamente não sobrevivia socialmente, sendo malvista, renegada ou ignorada. Neste momento histórico, a noção de indivíduo, na cultura brasileira, ainda não havia se enraizado e o bem-estar social significava antes de tudo o pertencimento a algum grupo familiar. O vínculo familiar era, portanto, cultuado como um valor indissolúvel e vigorava associado à ideia de prestígio social. "Quem não tem família já desperta pena antes de começar o entrecho dramático; e quem renega sua família tem, de saída, a nossa mais franca antipatia" (Da Matta, 1987, p.125).

Gilberto Freyre $(1951,1973)$ pesquisou e relatou a história da sociedade brasileira no período da colonização, explicitando como a nossa família, tanto no campo como na cidade, se formou a partir do regime patriarcal ${ }^{3}$ e sob a influência da miscigenação de três culturas: indígena, europeia e africana ${ }^{4}$. Neste contexto, desenvolveu-se uma estrutura social em que a família funcionava como um núcleo composto pelo chefe da família, o patriarca, sua mulher, filhos e netos, que eram os representantes principais; e um núcleo de membros considerados secundários, formados por filhos ilegítimos ou de criação, parentes, afilhados, serviçais, amigos, agregados e escravos. No comando, tanto do grupo principal como do secundário,

\footnotetext{
${ }^{3}$ Estudos demonstram que esse modelo patriarcal descrito por Freyre foi considerado por várias gerações de estudiosos (historiadores, antropólogos e sociólogos brasileiros) como critério e medida de valor para compreendermos a vida familiar ao longo do tempo (SAMARA, 2002). E, assim como ele, também Sérgio Buarque de Holanda (1982) e Antonio Candido (1951) descreveram o conceito de família patriarcal como o modelo das famílias de norte a sul do país, durante três séculos de sua história, segundo as características da grande parentela, sistema hierárquico, autoridade paterna prevalecente, monogamia e indissolubilidade do casamento.

${ }^{4}$ Darcy Ribeiro, Roberto Da Matta e Oliveira Viana, entre outros, pensaram nessa formação a complexidade da nossa sociedade. Somos mestiços originados da expansão européia do século XVI e do contato inédito entre povos americanos, europeus e africanos. Esse processo proporcionou a formação de uma população diferenciada que não pode negar a existência de elementos culturais diversos. Dessa forma, a constituição da família brasileira se daria a partir da formação de seu povo. Estas e outras questões encontram-se envolvidas na cultura e nas pessoas que aqui vivem, sendo repassadas às gerações através do processo educacional e da forma como se é criado.
} 
estava o patriarca, responsável por cuidar dos negócios e defender a honra da família, exercendo autoridade sobre toda a sua parentela e demais dependentes que estivessem sob sua influência.

Ainda dentro deste sistema patriarcal, desenvolveu-se o costume da primogenitura, em que o filho mais velho herdava todas as terras do pai. Se a família fosse composta de mais de um filho, os outros seriam encaminhados aos estudos para se formarem médicos, advogados ou mesmo padres, caso sua formação fosse religiosa (Cotrim, 2005, p.54). No caso das meninas, na maioria das vezes elas eram encaminhadas aos conventos, onde aprendiam a ler, cantar, escrever e bordar, enquanto não se casassem. Caso ficassem solteiras, a família deixaria um dote em dinheiro, escravos ou outros bens, que seriam entregues ao convento que conduziria a jovem à vida religiosa.

Em relação aos escravos, sua família geralmente era configurada de forma complexa e até violenta no interior das senzalas, pois a disputa pela aquisição de uma esposa era bastante acentuada, visto que o número de homens era superior ao de mulheres. Apesar de existirem escravos de diferentes grupos étnicos africanos, homens e mulheres preferiam se casar com indivíduos da mesma etnia. É importante ressaltar que os casamentos não ocorriam somente no interior das senzalas e tampouco apenas entre escravos, pois os alforriados que viviam nas cidades também se casavam. Além disso, não eram raros na sociedade colonial casais de negros libertos deixarem seus filhos para seus antigos senhores criarem. Na maioria das vezes, isso ocorria devido às precárias condições de vida em que os libertos se encontravam, não tendo condições de criar seus filhos (Cotrim, 2005, p.54).

Durante os três primeiros séculos, talvez um pouco mais, o matrimônio era algo extremamente restrito a poucas famílias, pois sua realização implicava um alto custo e o enquadramento em uma acentuada burocracia eclesiástica. A acentuada burocracia e a necessidade de grande soma em dinheiro acabaram afastando a população pobre do casamento, ficando este restrito a uma elite branca que via nele um símbolo de prestígio e estabilidade social. Desta forma, para a maioria da população pobre, restaram as uniões simples consideradas ilegais pela Igreja Católica. Esta complexidade para consolidar matrimônios considerados legais na Colônia refletiu muito da própria estrutura social da época. Ronaldo Vainfas fala sobre o casamento em sua obra Trópico dos Pecados 
O processo matrimonial era caro, lento e complicado, exigindo dos nubentes variados documentos e grandes despesas, incluindo certidões de batismo necessárias para a comprovação de idade núbil, atestados de residência importantes para o exame dos contratantes que tivessem residido em outras paróquias, e certidões de óbito do primeiro cônjuge no caso de viúvos, essenciais para evitar as frequentes bigamias daquela época. (Vainfais, 1989, p.42).

Se, por um lado, a Igreja Católica mostrou-se rígida com as uniões consideradas ilegais, pois considerava o casamento um sacramento, por outro o Estado português mostrou-se tolerante com as uniões consideradas ilícitas pelo clero, para as autoridades lusitanas, o interessante era a reprodução de mão-de-obra, o que não dependia da constituição de uma legalidade entre um homem e uma mulher.

Samara (2002) afirma que a família brasileira seria o resultado da transplantação e adaptação da família portuguesa ao nosso ambiente colonial, com suas normas, costumes e tradições familiares por sua vez influenciados pela sociedade europeia, tendo gerado um modelo com características patriarcais e tendências conservadoras em sua essência. Nesta mesma perspectiva, Costa (1989) aponta que a política econômica de Portugal foi decisiva na organização da família colonial brasileira. A estratégia mercantilista trouxe como consequência a multiplicação de favores e privilégios aos senhores rurais. A metrópole, interessada no lucro fácil sem investimentos, instigou a iniciativa privada dos colonos que trataram de impor a ordem social e econômica que mais lhes beneficiasse. $\mathrm{Na}$ prática, esta autonomia permitiu aos proprietários de terra governarem sozinhos nos três primeiros séculos de colonização.

No Brasil-Colônia, família passou a ser sinônimo de organização familiar latifundiária, o que provocou a instalação dessa sociedade do tipo paternalista, em que as relações de caráter pessoal assumiram extrema importância. Neste contexto, Samara enfatiza que a família patriarcal era a base deste sistema mais amplo "por suas características quanto à composição e relacionamento entre seus membros, que estimulavam a dependência na autoridade paterna e a solidariedade entre os parentes" (Samara, 2002, p.73 ). ${ }^{5}$

\footnotetext{
${ }^{5}$ Darcy Ribeiro, em O povo brasileiro (1995) dá conta de que o velho costume indígena de incorporar estranhos à sua comunidade representava para o português recém-chegado a aquisição imediata, através do casamento, de uma multidão espantosa de parentes. Sem essa prática, conhecida como cunhadismo, seria impossível a criação do Brasil. De fato, ela é fundamental para a defesa do território e à organização da economia colonial além dos muros casa grande e senzala.
} 
Entretanto, este patriarca orgulhoso a quem todos se submetiam era o grande senhor rural, proprietário de terras incomensuráveis, onde se plantavam as bases da economia brasileira: café, cacau, cana-de-açúcar e outras grandes lavouras. Não havia comunidades sólidas, sindicatos, clubes ou outros órgãos que reunissem pessoas de interesses similares. A grande família patriarcal, ocupava todos esses espaços e o que não fosse provido por ela representava um corpo estranho e indesejável. O próprio Estado, que, como ordem pública, deveria estar acima das questões familiares, esbarrava nestas quando necessitava intervir. Mas os governantes sabiam que essa família exclusivista, dobrada sobre si mesma e extremamente organizada era, por sua vez, o sustentáculo do Estado, pois impedia que a população, tão escassa e quase nômade, se diluísse neste imenso país.

A família patriarcal era, portanto, a espinha dorsal da sociedade e desempenhava os papéis de procriação, administração econômica e direção política. $\mathrm{Na}$ casa-grande, coração e cérebro das poderosas fazendas, nasciam os numerosos filhos e netos do patriarca, traçavam-se os destinos da fazenda e educavam-se os futuros dirigentes do país. Cada um com seu papel, todos se moviam segundo intensa cooperação. A unidade da família devia ser preservada a todo custo, e, por isso, eram comuns os casamentos entre parentes. A fortuna do clã e suas propriedades se mantinham assim indivisíveis sob a chefia do patriarca (Freyre, 1933).

Percebe-se, então, que a família patriarcal era o mundo do homem por excelência, crianças e mulheres não passavam de seres insignificantes e amedrontados, cuja maior aspiração eram as boas graças do patriarca. A soberania do masculino era de tal natureza que os varões não reconheciam sequer a autoridade religiosa dos padres. Assistiam à missa, sem a menor manifestação daquela humildade cristã do crente (própria das mulheres), assumindo sempre ares de proprietário da capela, protetor da religião e bom contribuinte da Igreja. Deste modo, neste universo masculino, os filhos mais velhos também desfrutavam de imensos privilégios, especialmente em relação aos seus irmãos e os homens em geral dispunham de diversas regalias, a começar pela dupla moral vigente, que lhes permitia aventuras com criadas e ex- escravas, desde que fosse guardada certa discrição, enquanto às mulheres tudo era proibido, desde que não se destinasse à procriação (Cotrim, 2005, p.57). 
Sem dúvida a família patriarcal foi um modelo de suma importância na sociedade colonial deixando raízes em nosso cotidiano. Entretanto, estudos mais recentes, como os de Eni de Mesquita Samara (1983) e Ângela Mendes de Almeida (1987), revelam que o modelo de família patriarcal não se manifestou de forma homogênea na América portuguesa, pois outros modelos, estruturas e relações também se constituíram, variando de acordo com a cultura, a região e a condição social de seus indivíduos. Por exemplo, se a denominação de "família patriarcal" serviu de base para a historiografia brasileira caracterizá-la como sinônimo de família extensa, devido aos estudos de Gilberto Freyre e Oliveira Vianna pesquisas mais recentes têm evidenciado que estas não foram as predominantes, mas sim, aquelas com estruturas mais simplificadas e menor número de integrantes: famílias pequenas, famílias de solteiros e viúvos, famílias de mães e filhos sem pais, famílias de escravos.

Podemos perceber que também no passado a configuração de família se alterava conforme os grupos sociais e as regiões do país. Os escravos forros viviam de um jeito; o poderoso da elite senhorial, de outro. O que não variava era o hábito, muito comum, de integrarem amigos e parentes à família. (Del Priore, 2006.) No entanto, pesquisadores posteriores os quais tiveram acesso a outros dados que anteriormente não eram vistos como fontes históricas e que hoje em dia são, principalmente devido ao avanço dos estudos culturais, tiveram leituras diferenciadas dos clássicos interpretadores da família patriarcal brasileira. Nessa perspectiva enquadram- se as historiadoras Samara (1983) e Correa (1982), que exploraram a história da família brasileira, ampliando a visão dos dados históricos, reelaborando os estudos anteriores, e reavaliando os critérios até então utilizados.

As investigações dessas autoras enfraqueceram as convicções de diversos historiadores, antropólogos e sociólogos que consideravam a família brasileira unicamente patriarcal. Na verdade, este modelo, até então, era considerado essencial. Ignoravam-se outras possíveis estruturas familiares que se organizaram em função do tempo, do espaço ou de algumas características sociais.

Estes estudos e pesquisas, iniciados a partir de meados dos anos 80, demonstraram haver outras configurações familiares que coexistiram com, ou mesmo predominaram sobre o modelo patriarcal. A descrição da família patriarcal latifundiária de Freyre $(1951,1973)$, portanto, não deve ser considerada como a única representação plausível para a família brasileira ao longo de sua história. 
Segundo Samara (2002), a descrição das famílias extensas do tipo patriarcal de Freyre foi predominante nas áreas de lavoura canavieira nordestinas, sendo inapropriadamente utilizada para as demais regiões, sem levar em conta etnias, temporalidades, grupos sociais, contextos econômicos regionais, razão de sexo e movimento da população.

Como podemos observar, em relação ao papel da mulher dentro da família durante os três primeiros séculos, percebemos certo exagero por parte dos historiadores e romancistas quando colocam o estereótipo do marido dominador e da mulher submissa. Existiam na realidade variações de comportamento de acordo com os diferentes níveis sociais das mulheres. A própria natureza do sistema patriarcal e a divisão de trabalho entre o marido e a esposa criaram, de certo modo, condições para a afirmação da personalidade feminina, dada a sua influência direta junto à família.

De acordo com Samara (1989) não são raros os exemplos de mulheres que, por ausência do marido ou viuvez, zelaram pelo patrimônio da família, gerindo propriedades e negócios. A esposa transformada em chefe domiciliar por morte do marido deveria, no entanto, justificar juridicamente esse encargo. Entretanto, é preciso também assinalar que, embora os estudos mostrem algumas evidências da liberdade de ação das mulheres, estas são incipientes e não podem representar o todo, já que esta liberdade era limitada pela concordância do homem. (Samara, 1989). Desta forma, a família nuclear também teve grande importância no processo de formação da sociedade brasileira.

Este tipo de estrutura familiar difere da tradicional família patriarcal, pois é composta apenas pelo núcleo principal representado pelo chefe da família, sua esposa e os seus descendentes legítimos. Nesta trajetória teórica não podemos deixar de mencionar Philippe Áries $(1991)^{6}$ o qual anuncia, em seu livro História Social da Criança e da Família, essas transformações nas relações família/sociedade a partir de meados do século XVIII, na Europa, quando a sociedade começou a manter a família "à distância, a confiná-la a um espaço limitado, aquém de uma zona mais extensa da vida particular". Isso significou literalmente fechar a porta da casa ao mundo externo, criando-se outras portas dentro da própria casa a fim de

\footnotetext{
${ }^{6}$ Apesar de Philippe Ariès ser um autor francês e esta pesquisa se propor a abordar o cuidado em família no contexto brasileiro contemporâneo, acreditamos ser relevante citá-lo, dada a frequência com que o autor aparece mencionado em estudos brasileiros sobre infância, família e cuidados parentais.
} 
separar os cômodos uns dos outros e isolar a criadagem em áreas separadas. A visita à casa ocorria apenas a convite do dono. A reorganização da casa e a reforma dos costumes deixaram um espaço maior para a intimidade, que foi preenchida por uma família reduzida aos pais e às crianças, e da qual se excluíam os criados, os clientes e os amigos. A preocupação maior com a formação dos filhos passou a canalizar a maior parte da energia da família e, sendo o estudo privilégio de poucas pessoas, essa educação dos filhos também passou a depender muito da experiência de vida dos próprios pais.

No decorrer da história brasileira, o início das transformações da configuração familiar patriarcal clássica para essa configuração mais moderna, denominada nuclear ocorreu a partir da chegada da Corte Portuguesa ao Rio de Janeiro e o início de uma vida social na Colônia. Almeida (1987, p.8-13) relata que a chegada da Corte Portuguesa ao Brasil (1808) trouxe consigo a influência árabe exercida sobre os portugueses, cuja característica era levar a família e a mulher para fora de casa. Além disso, a Corte também estabeleceu oportunidades de estudos e outras formas de ascensão social aos segmentos masculinos mais jovens da população. Sendo assim, a família patriarcal teria se transformado ao longo do século XIX, com filhos menos dependentes do poder patriarcal (com a possibilidade de carreiras autônomas ou políticas). Posteriormente, no final do século, a influência da burguesia industrial europeia atuaria no sentido inverso, levando a mulher para dentro de casa, para ser a "rainha do lar".

$\mathrm{Na}$ família nuclear brasileira, historicamente falando, quando seus componentes se casavam, constituíam sua própria família em outro domicílio; eram raros os casais que agrupavam genros, noras e netos em torno de seus filhos casados, o que nos leva a acreditar que, na família nuclear, diferentemente da patriarcal, não havia um total poder de controle por parte do chefe da família.

Se o comando do lar era responsabilidade da mulher, pois esta deveria administrar o lar e educar os filhos, a ausência do homem era comum em seu domicílio, devido à sua dedicação aos negócios, o que acabava diminuindo-lhe a autoridade paterna. O chefe da família cuidava dos negócios e tinha, por princípio, preservar a linhagem e a honra familiar, procurando exercer sua autoridade sobre a mulher, filhos e demais dependentes. As mulheres, depois de casadas, passavam da tutela do pai para a do marido, cuidando dos filhos e da casa no desempenho das 
atividades domésticas. Segundo Costa (1989), a permanência da mulher no interior da casa devia-se, antes de mais nada, à sua função econômica.

Dependendo juridicamente, afetivamente, moralmente e religiosamente do marido, prestava-se docilmente a organizar a produção econômica da casa, supervisionando o trabalho escravo. Mão-de-obra gratuita, a mulher permitiu por muito tempo a autossuficiência das residências, fenômeno necessário ao despotismo senhorial sobre a cidade (...). A dona de casa era enfermeira, médica, sacerdote e professora, distribuindo medicamentos em caso de doenças, ensinando aos filhos as primeiras letras e cumprindo uma enorme quantidade de obrigações religiosas (terços, novenas, promessas, entre outros). (Costa, 1989, p.93).

Durante o século XIX, o desenvolvimento econômico no Sul do país provocado pela cafeicultura e alguns acontecimentos políticos importantes, como a Independência em 1822 e República em 1889, aliados à abolição da escravatura e à chegada de imigrantes, acentuaram o desenvolvimento urbano e a geração de papéis sociais informais, enfraquecendo o sistema patriarcal brasileiro e a sua rigidez, com as tarefas divididas entre homens e mulheres.

Nas primeiras décadas do século $\mathrm{XX}$, as indústrias começam a se desenvolver, incrementando a oferta de trabalho fabril e burocrático. Ocorre alguma inserção feminina nestes mercados, e as mulheres passam a exercer funções remuneradas combinadas às atividades domésticas. Tanto mulheres solteiras trabalhavam quanto mães e donas de casa, que passaram, então, a contribuir com a renda familiar (Samara, 2002). No entanto, Samara (1986) também ressalta que, no recenseamento de famílias de 1936, era pequeno o universo das famílias com coabitantes, parentes, amigos e afilhados. Esta mudança redundou num confinamento maior da mulher ao ambiente doméstico, ficando com a responsabilidade total pelos cuidados dos filhos e da casa, enquanto o marido provia o sustento da família. Desta forma, a realização da mulher se dava através do marido e filhos: seu "status" social era o do marido e suas qualidades pessoais valorizadas pela sua capacidade de gerenciar o lar e formar os filhos para se tornarem cidadãos honestos e honrados para servir a sociedade.

Ainda no século XX, esta mudança lenta, porém evidente, da configuração da família evidenciou-se pelo menos na prática, já que teoricamente a autoridade ainda permanecia nas mãos do sexo masculino. Observa-se, então, a existência de dois quadros: de um lado, as mulheres da família mais abastadas, ocupadas com 
bordados, músicas, filhos observados por empregados; de outro, as mais pobres, de participação mais ativa nos negócios, contribuindo com recursos para a manutenção da casa. Em São Paulo, de acordo com Samara (1989, p.98), "além das atividades avulsas (doceiras, engomadeiras, cozinheiras e costureiras), apareceram teares domésticos (rendeiras e tecelãs) e as pequenas indústrias". Assim, as significativas mudanças que ocorreram na sociedade brasileira modificaram a estrutura da família. Sua transformação de sociedade rural, na qual predominava a família patriarcal e fechada em si mesma, para uma sociedade de bases industriais, mesmo que incipientes, com as suas implicações de mobilidade social, geográfica e cultural, acarretou transformações igualmente marcantes na estrutura do modelo tradicional de família (Almeida, 1987).

Da segunda metade do século XX em diante, outras transformações mais radicais, aconteceriam, a saída da mulher não pobre para o mercado de trabalho, a educação dos filhos, a impessoalidade nas relações sociais, o controle de natalidade e o enfraquecimento dos laços de parentesco são as grandes mudanças apontadas sobre a família moderna (ib, id). Em todo o mundo, o conceito de família nuclear e a instituição casamento intimamente ligada à família se modificaram. A expressão mais marcante dessas transformações ocorreu no final da década de 60; cresceu o número de separações e divórcios, a religião foi perdendo sua força, não mais conseguindo segurar casamentos com relações insatisfatórias. A igualdade passou a ser um pressuposto em muitas relações matrimoniais. A partir daí, surgem inúmeras organizações familiares alternativas: casamentos sucessivos com parceiros distintos e filhos de diferentes uniões; casais homoafetivos adotando filhos legalmente; casais com filhos ou parceiros isolados ou mesmo cada um vivendo com uma das famílias de origem; as chamadas "produções independentes" tornam-se mais frequentes; e, mais ultimamente, duplas de mães solteiras ou já separadas compartilham a criação de seus filhos. Chegamos ao século XXI com a família pluralista, como tem sido chamada, pelos tipos alternativos de convivência que apresenta.

Hoje em dia, periódicos trazem artigos de diversas áreas de estudo os quais tendem a debater e afirmar que, nas últimas décadas, a instituição família passa por uma "crise" em decorrência de vários fatores, entre os quais, destacamos: a baixa taxa de fecundidade, o aumento da expectativa de vida e, consequentemente, a crescente proporção da população com mais de 60 anos. Juntamente a esses fatores, 
o declínio do casamento e a banalização das separações também são fatores constituintes da chamada "crise". Entretanto, o que caracteriza esse processo não é propriamente o enfraquecimento da instituição família, mas o surgimento de novos arranjos familiares, de novas relações entre os sexos, numa perspectiva igualitária, mediante o maior controle da natalidade e a inserção massiva da mulher no mercado de trabalho, entre outros aspectos. (Almeida, 1987, p.13-17).

Dados do IBGE (2007) demonstram que a composição das famílias brasileiras, especialmente nas últimas três décadas, vem passando por várias alterações do ponto de vista demográfico e, embora estas alterações ocorram de forma diferenciada nas diversas regiões do país, algumas ocorrem de forma mais ou menos similar, como a redução da natalidade e o aumento da longevidade das pessoas. As estatísticas demonstram, portanto, que as famílias vêm se tornando menores e com um número maior de idosos em sua composição.

No decorrer da próxima seção, trataremos da Roda dos expostos, pois acreditamos ser um assunto relevante à discussão proposta, cuja estrutura contribui para compreendermos a lógica vigente e a quais fatores importavam dentro das relações familiares.

\section{2. \\ Roda dos expostos e a lógica Médico- higienista}

$\mathrm{Na}$ época colonial e durante o Império, "exposto" e "enjeitado" constituíam termos recorrentemente empregados na sociedade brasileira para nomear a criança abandonada. "Exposto" e "enjeitado", segundo o dicionário da língua portuguesa de Antonio de Morais Silva (1831), correspondia àquele e/ ou àquela que era abandonado (a) na Roda, aparelho, em geral, de madeira, do formato de um cilindro, com um dos lados vazados, assentado em um eixo que produzia um movimento rotativo, anexo a um asilo de menores. A utilização deste tipo de engrenagem permitia o ocultamento da identidade daquele (a) que abandonava. A pessoa que levava e lançava a criança na Roda não estabelecia nenhuma espécie de contato com quem a recolhia do lado de dentro do estabelecimento. A manutenção do segredo sobre a origem social da criança resultava da relação promovida entre 
abandono de crianças e amores ilícitos. Os espaços especialmente destinados a acolher crianças visavam, em um primeiro momento, absorver os frutos destas uniões. Com o tempo, estas instituições passaram a ser utilizadas também por outros motivos; indivíduos das camadas populares, por exemplo, abandonavam seus filhos na Roda por não possuir meios materiais de mantê-los e criá-los.

Os primeiros asilos surgiram nas cidades de Salvador e Rio de Janeiro durante o século XVIII. Em 1693, entretanto, já havia sido enviada ao governador da capitania do rio de Janeiro, Antonio Paes de Sande, uma carta régia, na qual se determinava que os "expostos" fossem criados às custas dos cofres públicos. Através desta medida, os "enjeitados" deixariam de ser jogados nas igrejas, nas portas das residências, nas ruas e praças, na dependência da "caridade pública". Durante mais de oitenta anos, no entanto, os termos da carta régia permaneceram esquecidos. Foi em 1738, que Romão Duarte doou uma quantia que permitia a fundação de um estabelecimento voltado para o recebimento e abrigo de crianças abandonadas na cidade do Rio de Janeiro. A partir de então, o benfeitor seria reconhecido como o "pai dos sem pais".

A Casa dos Expostos foi criada dentro dos quadros da Santa Casa de Misericórdia do Rio de Janeiro e se encaixava no modelo que caracterizava o cuidado com populações carentes no Rio de Janeiro. A lógica que presidia a esta orientação combinava com uma prática caritativo-assistencial; o cuidado com as populações "carentes" estava, deste modo, sob a responsabilidade de irmandades religiosas. A história da assistência das Misericórdias de origem portuguesa tem-se assinalado pela pregação da caridade e solidariedade cristã.

O estudo de uma instituição como a Casa dos expostos implica na reflexão sobre um determinado tipo de moral que conduzia as relações familiares. Os asilos de "enjeitados" emergiam na condição de reguladores dos possíveis "desvios" familiares; um lugar para os filhos de uniões ilegítimas, os que não possuíam história, os "sem-família". No Brasil, estes estabelecimentos surgiam dentro da estrutura familiar colonial. ${ }^{7}$ Os preceitos e regras que criavam e mantinham

\footnotetext{
${ }^{7}$ Os asilos para menores abandonados, os conventos e os recolhimentos para mulheres foram criados a partir do século XVIII. Estes estabelecimentos surgiram em centros urbanos no bojo de um movimento de moralização dos comportamentos femininos e tinham como objetivo a preservação da "honra" das mulheres pertencentes aos segmentos médios e altos da população. As mulheres destinadas, em princípio, para o casamento, as que escapavam ao matrimônio eram encaminhadas para ordem religiosa, onde tomavam o hábito cortando, assim, os vínculos com o mundo exterior.
} 
estabelecimentos como a Roda dos expostos, encontravam no "cristianismo" seu campo de referência. Para a moral cristã, as práticas reprodutivas, estavam restritas aos limites do casamento. A procriação fora do casamento era alvo de recriminação e estava sujeita a sanções, tanto em nível religiosos, como social, já que ambas instâncias tendiam, neste caso específico, a se confundirem.

A fonte principal para a presente reflexão são as teses da faculdade de Medicina sobre a Roda dos Expostos, produzidas entre 1845 e 1860. Como requisito para o término do curso de medicina, o candidato a médico deveria defender uma tese a partir de um dos pontos elaborados pela faculdade. Entre os diversos temas, colocava-se um referente à Casa dos expostos. As teses buscavam justificar a existência de estabelecimentos como a Roda, através de argumentos médicos para a manutenção da mesma, apresentando elementos que ajudassem a construir a concepção médico-higienista da mulher que abandonava o filho. Estas teses mostram que a atenção médica se voltava para a definição de papéis e comportamentos dentro do cenário familiar. E, na re-atualização da família, à mulher cabia menção especial. Ela aparecia como peça central nas dissertações médicas, o seu domínio era o espaço da casa. Observa-se, portanto, a ênfase em um tipo particular de mulher: a mulher "boa" mãe e "boa" esposa. Em contraposição, outros tipos de mulheres eram apresentados: a mundana, a mulher de "vida fácil", a prostituta. Aqui se situavam as mulheres que recusavam o desempenho do papel de esposa e mãe. As mulheres que abandonavam seus filhos se enquadravam, segundo os relatos médicos, neste último grupo. Por isso a defesa em prol da preservação de espaços especiais para o abrigo de "amores adulterinos". A Roda era, acrescentam os higienistas, um problema de moral familiar e pública; os asilos constituíram um "remédio" possível à "má” conduta da mulher, permitindo que ela, "arrependida", levasse uma vida "digna".

O Brasil expressava o descompasso entre uma organização social tradicional, de base agrária escravista, e ideias e práticas de caráter progressista. E, neste contexto, a medicina higienista, tal como presente nos textos da faculdade de medicina, apresentava os paradoxos e ambiguidades da sociedade brasileira da época. Em relação à estrutura familiar, o seu discurso era claramente normativo; priorização do cuidado e da educação dos filhos, a mulher voltada para as funções de esposa e mãe. Jurandir Freire Costa, em sua obra Ordem Médica e Norma Familiar, mostrou este processo de progressiva medicalização das famílias dos 
setores de elite da sociedade brasileira, a partir de meados do século XIX; a produção de uma norma familiar de comportamento. Sob o ponto de vista do discurso médico sobre a Casa dos Expostos, contudo, a sua racionalidade se perdia. No que dizia respeito à Roda, os higienistas exprimiam o seu compromisso com o passado e, com isso, buscavam na religião católica a fonte de inspiração.

As Rodas, justificavam-se os médicos, correspondiam a um sinal de civilização, pois a edificação de espaços para o acolhimento dos "fillhos do pecado", apontaria para o fim dos tempos de "barbárie", ou seja, tempos associados a abandonos de crianças em vias públicas, sujeitas à fome, frio e morte.

Para além da "caridade" que a Roda exprimia, tratava-se de favorecer o ocultamento das condições em que a criança era gerada. O “exposto”, provável fruto de uma união ilícita, encontraria na Roda um lugar de socorro e acolhida. Os asilos para "enjeitados" constituíam, como é possível observar, um meio de preservação da família e de salvação da sociedade. A deterioração dos costumes produzia, segundo as teses, o afrouxamento dos laços familiares, arrastando a sociedade para a corrupção e miséria.

Desta maneira, a Roda era vista, pelas teses, como uma "mal menor" face aos efeitos resultantes da exposição da mulher, como mãe de um filho natural, perante a sociedade. O filho representava o fruto de um pecado, prova de sua "fascinação" e "delírio". A reprodução estaria, para os médicos, restrita aos limites de uma união ilegítima; fora do casamento, a maternidade condenava a mulher a uma vida "não digna". Para ambos, mãe e filho, a Roda significava uma "solução menos dura" e preservava-a da opinião pública, sempre hostil, intolerante e inflexível.

Destruir a Roda e o segredo que a envolvia seria lançar o ferrete da ignomínia sobre ela (famílias); seria patentear e entregar ao juízo inexorável do público, um ato muitas vezes filho de um momento de fraqueza, a que uma inocente e cândida donzela é muitas vezes arrastada. Pelas palavras e promessas fementidas, encobertas de aparente mel, mas repletas de negro fel, que partem dos lábios de um sedutor, sem moral e sem consciência. (Pederneiras, 1855, p.21).

Transformações ocorridas na sociedade brasileira nos anos que seguiram à vinda da corte portuguesa para o Rio de Janeiro favoreceram o surgimento de condições para o crescimento e dinamização sócio-político-econômica da cidade. Estas alterações permitiam que setores específicos da sociedade tivessem acesso a 
ideias e práticas ligadas ao avanço do capitalismo. Entre estes setores teve destaque o dos médicos higienistas. Da Faculdade de Medicina partia um movimento de reforma da vida das populações urbanas. Para tanto, imprimia-se uma direção de modernização da sociedade, submetendo os sujeitos a "novos" comportamentos. Rompia-se, deste modo, com o monopólio colonial, naquilo que ele representava de arcaísmo, buscando-se o direito de passagem para o mundo civilizado.

O pensamento médico-higienista sobre a Casa dos expostos, aqui apresentado, indicou que, com relação ao abandono infantil, ele reproduzia a velha ordem colonial. Neste retorno, a mulher e a família estavam preservadas. Provavelmente, não se tratava de defender a estrutura familiar da colônia, mas sim, através de uma atualização de papéis, eleger um perfil específico de mulher passiva e ingênua, direcionada ao casamento e â maternidade. Para tanto, a higiene concentrava suas forças no ataque às figuras masculinas, consideradas nocivas para a sociedade.

De fato, a produção médica sobre a Roda esteve caracterizada pela ambiguidade, pela descontinuidade do discurso; por um lado abrangente, delineado pela ciência e, por outro, restrito à religião, produzindo os dilemas e impasses que davam sentido à formação social brasileira da época.

A seguir trataremos dos estudos de gênero, os quais são fundamentais para nosso estudo e tornaram- se centrais nas tendências historiográficas dos estudos sobre famílias nos últimos anos no Brasil.

\section{3.}

\section{Bases fundadoras das relações de gênero}

O período patriarcal foi o marco inicial da soberania do homem sobre a mulher. Assim sendo, o poder político absolutista do rei foi transferido ao patriarca nas famílias, fazendo com que o pai detivesse poder ilimitado sobre a família, da mesma forma como o monarca detinha poder sobre sua nação. Corroborando com esta afirmação, Saraiva descreve: “Tanto o poder paterno era o poder monárquico, quanto vice-versa. O pai governava segundo sua vontade (uma vontade com força absoluta, ilimitada e arbitrária)" (1998, p.48). O poder do rei estava intimamente 
relacionado ao poder de Deus e, assim sendo, como no espaço público havia uma associação entre Deus e o monarca, no âmbito privado da família houve um paralelo entre o poder de Deus sobre todos e o poder do pai sobre a família.

Podemos perceber, então, que o patriarcado estabeleceu o masculino como referência e o feminino como sem valor. Para Saraiva, "o patriarcado é a exaltação dos valores masculinos tornados naturais e sustentados num princípio que se propunha inabalável, o do Pai” (Saraiva, 1998, p.45).

Ainda segundo este autor, as mulheres não foram valorizadas nem mesmo na qualidade de mães, pois os homens foram considerados os únicos responsáveis pela procriação dos filhos. As mesmas eram vistas como recipientes vazios a serem preenchidos pelos homens, ou seja, carregar a criança no ventre tornou-se o único papel considerado feminino, sem qualquer participação da mulher na concepção. Esta extrema valorização da paternidade, associada ao advento das guerras, explica a hegemonia masculina na estrutura patriarcal, pois neste contexto, determinados povos precisavam dominar outros, tarefa considerada ideal para os homens e, assim sendo, foram criados valores compatíveis com as necessidades daquele período: honra, soberania, poder e dominação. Estes valores passaram a determinar a masculinidade, formando-se a verdadeira identidade masculina- guerreiro, soberano e dominador (Saraiva, 1998).

Durante este período, os casamentos eram arranjados pelos pais dos noivos, seguindo os interesses econômicos da época. Neste período, não havia o ideário amoroso de família, uma vez que essa instituição não era constituída a partir de vínculo afetivo existente entre o casal; a representação da família não era como a que observamos nos dias atuais: uma instituição que deve garantir segurança material e psicológica aos seus membros.

De acordo com o historiador Philippe Ariès (1978), tratava-se de uma instituição cujo objetivo voltava-se para atender, primordialmente, aos interesses patrimoniais e de agregação, não existindo como um sentimento ou valor. $\mathrm{O}$ sentimento de família só foi possível, segundo Saraiva (1998), com o aparecimento da ideia de amor romântico e do sentimento de infância, concepções estas surgidas na modernidade, quando se passou a valorizar a união pelo amor e a perceber as crianças como seres que necessitavam de cuidados especiais; o que tornou a afetividade entre pais e filhos culturalmente maior. De acordo com Oliveira (2011), 
no período moderno, marcado pelo advento da família burguesa, também se consolidou a noção de privacidade familiar.

A partir de então, a responsabilidade pelo cuidado das crianças foi atribuída às mães, aquela que deveria atender as necessidades materiais e afetivas de sua prole. Como podemos notar, a sociedade moderna herdou da patriarcal a representação dos homens como superiores às mulheres, porém de forma ressignificada. Com a industrialização e a decorrente valorização do trabalho remunerado, a representação do guerreiro foi associada às características primordiais à reprodução do modo de produção capitalista; racionalidade e capacidade de trabalhar. Desta maneira, o homem moderno perdeu o papel político que possuía na sociedade patriarcal, assumindo o papel social de trabalhador, aquele responsável por prover a família, garantindo seu domínio sobre a mesma.

Segundo Bruschini (1993), com as transformações ocorridas com a industrialização, acentuou-se a divisão de duas esferas distintas na sociedade: de um lado a unidade doméstica, de outro a unidade de produção. Essa fragmentação correspondeu a uma divisão sexual do trabalho mais rígida do que a que predominava anteriormente: "à mulher coube principalmente a divisão de tarefas relativas à reprodução da força de trabalho na esfera privada do lar e sem remuneração, enquanto ao homem coube o trabalho produtivo extra lar, pelo qual passou a receber remuneração " (Bruschini, 1993, p. 65).

Verificamos que o mundo do trabalho do homem era afastado de tudo que fosse relacionado à emoção, incluindo expressões de sentimentos como afeto e amor. Estas habilidades foram atribuídas às mulheres, que vistas como sensíveis e afetivas, passaram a ser consideradas ideais para assumirem responsabilidades associadas ao cuidado da família. A despeito do assunto, Saraiva descreve que:

O poder da mãe é exaltado como pureza, instinto e capacidade ilimitada para cuidar e amar os filhos. A sociedade industrial, ao afastar pai e filho, coloca a mãe como responsável pela educação e instrução, pois a função de nutriz é desdobrada e associada à de formação. (Saraiva, 1998, p.72).

Como podemos perceber, a fixa divisão sexual do trabalho, diferenciando os papéis do homem provedor e da mulher cuidadora, constituiu-se na principal característica do modelo de família nuclear burguesa (Morgado, 2001). A ideologia transformou esta rígida divisão sexual do trabalho em uma divisão natural, como se 
pertencesse à biologia de cada sexo (Bruschini, 1993). Segundo Saraiva (1998), a modernidade representou, ao mesmo tempo, um avanço e um retrocesso nas relações de gênero. Um avanço porque, quando comparado ao período feudal, concedeu poder às mulheres, pois estas devem ser 'boas' esposas e donas de casa, dever este quase tão fundamental quanto o dos homens, que era o de produzir riquezas. Para que as mulheres assumissem estas responsabilidades, foram-lhes conferidas qualidades altruístas: “devoção aos outros, fortaleza moral, afetividade, delicadeza, sensibilidade" (Quintaneiro, 1995, p.46).

Seguindo esta maneira de pensar, Saraiva (1998) acrescenta que, "ao irem se tornando 'especialistas', seja pela maternidade ou pelo domínio nas questões da intimidade, as mulheres foram ocupando postos que, sem dúvida, também o são de poder" (Saraiva, 1998, p.64). Por outro lado, a modernidade também representou um retrocesso porque restringiu as mulheres ao espaço privado e, ao considerá-lo como de menor valor que o espaço masculino (público), ressignificou a ideologia de superioridade dos homens.

Ainda sob a ótica de Saraiva (1998), este afirma que o modelo de família nuclear, com sua rígida divisão de papéis de gênero, prevalece como dominante na sociedade contemporânea, principalmente no que se refere ao campo ideológico. Todavia, como vimos, não se trata de um modelo natural, mas de um fenômeno social e historicamente construído e, portanto, passível de ser modificado. O caráter histórico da família possibilita-nos desmistificar a percepção, atualmente existente, de que essa instituição é a base do amor e o local da felicidade (Stamm \& Mioto, 2003). Esta maneira de perceber a família pode influenciar profissionais, levandoos a naturalizar as relações a partir do modelo socialmente construído do que deve ser uma família e como devem comportar-se os pais e as mães.

A desigualdade de gênero na cena contemporânea está demarcada, também, pela inserção das mulheres em tradicionais espaços masculinos e pela menor abertura para a participação dos homens nas tarefas historicamente femininas. De acordo com Saraiva (1998), dentre os homens existe um grande temor à feminilização e, por esse motivo, eles procuram se afastar do que culturalmente acreditam pertencer ao feminino, incluindo o campo da afetividade. Estas concepções sobre comportamento dos homens muitas vezes limitam novas maneiras de agir do homem, pois os que buscam romper com o modelo hegemônico de masculinidade podem ser vítimas de preconceitos. 
Ainda segundo Saraiva (1998), muitos são os que desconfiam dos homens que, procurando incorporar a afetividade à sua identidade masculina, reivindicam participar do cuidado das crianças, por vezes, desconfia-se da sua sexualidade ou associam-no a um abusador.

Outro fator importante de ser abordado, é a entrada das mulheres, providas de boa condição financeira, no mercado de trabalho remunerado, pois a mesma tem gerado consequências para as famílias. A primeira é a ampliação do poder de barganha da mulher no âmbito doméstico, uma vez que quase sempre a sua contribuição financeira é decisiva para o sustento da casa. A dimensão econômica é, portanto, relevante para determinar o grau de autonomia feminina. Segundo pesquisa realizada por Araujo e Scalon (2003), no aspecto ideológico da nossa sociedade contemporânea, a capacidade de consumo confere status aos indivíduos. Dessa forma, o trabalho remunerado feminino significa, para as mulheres, a aquisição da identidade de consumidoras, o que as valoriza socialmente. A respeito da dupla jornada de trabalho, Ridenti (1998) destaca que diferentemente dos homens, que têm o status definido pelo sucesso profissional, as mulheres tenderão a ser valorizadas apenas se conseguirem articular o sucesso do trabalho remunerado com as tarefas domésticas.

Ainda abordando determinadas transformações ocorridas na sociedade, Lins de Barros (2008) estuda as mudanças e permanências de modos de vida e de valores entre as gerações de mulheres de uma mesma família de camadas médias. Segundo o estudo, a participação feminina no âmbito público possibilita outros avanços e/ou alterações nos tradicionais comportamentos familiares, dentre os quais destacamos: a maternidade como uma opção em vez de um dever, a postergação da primeira união ou do nascimento do primeiro filho, o decréscimo do índice de reprodução, o aumento do divórcio- levando à reconfiguração da família e da conjugalidade. No decorrer da pesquisa realizada por Lins de Barros (2008), percebemos as diferentes formas de olhar para questões variadas entre as gerações, dependendo do contexto de interação social a que pertenciam e biografia das mulheres entrevistadas.

Como estamos verificando, ao longo de toda história e independente das diversas configurações que possa assumir, a família é caracterizada também por seu papel de cuidado dos membros. Todavia, a concepção de família pode variar dependendo de determinados fatores, tais como o enfoque dado, história e olhar do pesquisador, o contexto a que pertence. 
Um conceito de família que consideramos abrangente e compatível com a realidade contemporânea foi desenvolvido por Mioto (1998), que entende por família,

[...] um núcleo de pessoas que convivem em determinado lugar, durante um lapso de tempo mais ou menos longo e que se acham unidas (ou não) por laços consanguíneos. Ele tem como tarefa primordial o cuidado e a proteção de seus membros, e se encontra dialeticamente articulado com a estrutura social na qual está inserido (Mioto, 1998, p.21).

Para a autora, cabe à família cuidar de seus membros e este cuidado é diretamente influenciado pelos contextos políticos, sociais e ideológicos.

Ainda sob a perspectiva de Mioto, a família possui um caráter histórico, ou seja, não se define como um grupo natural, mas como um grupo social, historicamente construído. Esta forma de encarar a família é bastante relevante, pois é comum pensarmos esta instituição como local de afeto e proteção e muitas vezes não é isto o que observamos na prática, sendo ela por vezes, local perigoso tanto para crianças e adolescentes, como para mulheres.

Oliveira (2011) propõe que "Buscar compreender as concepções de família na atualidade requer reconhecer a historicidade das formas de organização familiares ao longo da história da humanidade, o que facilita a não naturalização do que se pode ver hoje" (Oliveira, 2011, p.55), corroborando com o pensamento de Mioto de que é primordial estudar a história para entendermos as variadas formas de as famílias funcionarem e cuidarem de seus membros.

A família como unidade dinâmica no decorrer de sua história tem passado por constantes modificações, o que torna difícil seguir um único curso. Muitas vezes, tomamos como referência nossos próprios valores e modos de vivenciar família, sendo primordial despirmos de conceitos preestabelecidos com a finalidade de enxergarmos cada família como única. Conforme assinala Mioto, “[...] ao falarmos de "famílias" devemos nos ater à sua especificidade, sua particularidade, posto que as famílias diferem significativamente entre si nos diversos momentos da história humana" (Mioto, 1997, p.162). Desta forma, cada família possui uma dinâmica própria construída por seus membros ao longo do tempo.

Ainda acerca dos diversos arranjos que as famílias contemporâneas podem assumir e dos novos padrões de conjugalidade, Araujo e Scalon (2003) observam 
que, a partir da década de 1970, as famílias brasileiras ficaram menores, visto que aumentaram aquelas compostas por somente um indivíduo, as monoparentais, as formadas por casais do mesmo sexo, e as constituídas por casais sem filhos. A diversidade de arranjos existentes na cena contemporânea brasileira foi formalmente reconhecida a partir da publicação da Constituição de 1988, com exceção das famílias formadas por casais homoafetivos, que somente foi reconhecida em 2013, quando o Conselho Nacional de Justiça aprovou uma resolução que obriga todos os cartórios do país a celebrar casamentos entre pessoas do mesmo sexo. Deste modo, a entidade familiar passou a ser constituída pela união estável entre o homem e a mulher ou pelas famílias monoparentais, em que o homem ou a mulher assume as responsabilidades. Do ponto de vista das relações de gênero, essa existência de novos arranjos familiares coloca em questão a hegemonia da família nuclear, como observado por Stamm e Mioto (2003), e possibilitam o enfraquecimento da autoridade patriarcal, como ressaltado por Araujo e Scalon (2003)

Bilac (1995) também investiga as mudanças ocorridas nas famílias, porém sob o prisma das diferenças entre classes sociais. Segundo a autora, as camadas populares brasileiras valorizam o modelo de família nuclear - pai trabalhador, mãe em casa e criança na escola -, mas suas possibilidades de efetivá-lo restringem-se a poucos, uma vez que é necessário um nível mínimo de participação social para que esse modelo seja possível: acesso ao trabalho regular, à moradia e à escola. $\mathrm{O}$ retrato mais fidedigno dessas famílias, que são não raro obrigadas a aceitar empregos precários, é o de se ampliarem para abrigar parentes e de recorrerem ao trabalho feminino, embora mais precário que dos homens.

Ainda de acordo com Bilac (1995), o grande número de famílias chefiadas por mulheres nestas camadas não significa a preferência ao exercício de um modelo alternativo de relações familiares, mas a impossibilidade de realização do modelo preferencial: o da tradicional família nuclear. É importante ressaltar que, apesar de relevante para nosso estudo, a pesquisa de Bilac foi realizada há vinte e um anos atrás, podendo ter havido alterações ao longo deste período.

No âmbito privado, podemos observar aspectos inovadores dos comportamentos familiares: homens exercendo a paternagem, querendo decidir sobre quando e como ter filhos e reivindicando a guarda dos seus filhos ou a adoção de crianças, mesmo sendo solteiros; e mulheres não aceitando passivamente a dupla 
jornada de trabalho e construindo projetos para além da maternidade (Ridenti, 1998). Seguindo esta linha de pensamento, podemos acrescentar a afirmação de Araujo e Scalon (2003): "no Brasil as relações de gênero na família mudaram" (Araujo \& Scalon, 2003, p.66). Entretanto, como descrito pelas mesmas autoras, as famílias ainda conservam, "na natureza de sua interação, o princípio tradicional da divisão sexual do trabalho - mulheres e homens com papéis diferenciados - e a predominância do padrão de domesticidade, que confere desvantagens às mulheres na vida social em geral" (Araujo \& Scalon, 2003, p.66).

A sociedade contemporânea é, portanto, marcada pelo conflito entre a herança conservadora e as concepções contemporâneas (Castells, 2000), uma sobrepondo-se à outra em determinados momentos da vida social e em determinados contextos familiares. As continuidades da herança conservadora no âmbito familiar são demarcadas, fundamentalmente, pelo fato de que os homens continuam sendo percebidos como provedores e as mulheres como cuidadoras da família. Desta forma, como discutido por Ridenti (1998), frequentemente, só é permitido aos homens a assunção dos espaços tradicionalmente femininos se eles mantiverem a provisão como o seu papel principal. Por mais que se encontrem pais reivindicando o que Costa (2002) nomeia de dimensões femininas na masculinidade, o trabalho remunerado e o sustento dos filhos continuam sendo considerados os papéis definidores de suas identidades masculinas e paternas.

Ainda sobre a percepção das atitudes de homens e mulheres na esfera familiar, Araujo e Scalon (2003) sustentam que chega a ser surpreendente o fato de haver atividades domésticas praticamente inexploradas pelos homens, tais como lavar roupa, passar e cozinhar. Estas práticas demonstram que "a divisão sexual do trabalho doméstico ainda continua sendo amplamente dominada pelo padrão tradicional" (Araujo \& Scalon, 2003, p.47). Assim, de maneira geral, os homens continuam a desempenhar papel secundário e bastante seletivo no que se refere à realização das demais tarefas relativas ao espaço doméstico (Carvalho et al., 2008). Todavia, Araujo e Scalon (2003) ressaltam que é "no envolvimento masculino com os filhos que se percebe um quadro mais positivo" (Araujo \& Scalon, 2003, p.50).

Considerando o exposto, podemos concluir que, hegemonicamente, o trabalho relacionado com a reprodução social permanece como responsabilidade feminina, ainda que isso signifique sobrecarga na jornada das mulheres inseridas no mercado de trabalho. Por outro lado, os homens, ainda que de modo embrionário, 
exercem o papel de cuidado dos filhos. A participação das crianças no interior das famílias também é uma questão a ser considerada quando se pensa em mudanças e permanências do modelo tradicional de família. As crianças brasileiras têm legalmente assegurado o reconhecimento de que são sujeitos de direitos, entretanto, como descrito por Oliveira (2011), na prática, muitas vezes, elas são tidas como propriedades de seus pais, o que nos remete à lembrança da posição subordinada tradicionalmente atribuída aos filhos nas famílias. Esta permanente imagem de submissão confere aos pais legitimidade social para tomar todas as decisões acerca da vida das crianças, sem que estas sejam respeitadas e ouvidas em seus desejos e opiniões.

A respeito de como o viver em família funciona, Szymanski (2005) alerta para a existência de uma dualidade, que foi por ela denominada de 'família vivida' e 'família pensada'. A família pensada diz respeito a um modo considerado ideal de viver, com regras e diretrizes que supostamente teriam de ser seguidas pelos integrantes da família. Este modelo ideal é constituído por bases que decorrem da cultura de determinada sociedade, transmitida entre gerações, e da cultura familiar, visto que cada família forma suas próprias regras, ritos e jogos.

Szymanski (2005) identifica que o modelo de família brasileiro tido como ideal tende a ser o da família nuclear burguesa, visto que este permanece enraizado no imaginário social. Assim, a 'família pensada' é aquela constituída pela união exclusiva de um homem e uma mulher, com compromisso de acolhimento e cuidado para com as pessoas envolvidas; esta família funciona dentro de uma ordem estabelecida de autoridade do homem/pai e, nesse contexto, pressupõe-se uma estabilidade do modelo pai-mãe-filhos. A autora ressalta que as famílias que não conseguem viver neste padrão podem ser percebidas, por elas mesmas e pela sociedade, como desestruturadas, incompetentes e inferiores. Entretanto, a 'família vivida', a que de fato existe, tende a diferir da 'pensada' porque, no agir concreto do quotidiano, as regras do modelo burguês nem sempre são seguidas (Szymanski, 2012). "Se, no discurso, elas não são contestadas, o mesmo não ocorre na ação que, aberta ou veladamente, aponta muitas vezes para a direção oposta a do pensado" (Szymanski, 2012, p.36).

Embora a família que se vive possa diferir muito do modelo estruturado de família nuclear burguesa, isso nem sempre significa sua aceitação ideológica como 
alternativa. O modelo de família pensada permanece impondo normas de conduta e desvalorizando o que foge desse padrão (Szymanski, 2012).

Sob o viés de Elsen (2002), a respeito das diversas formações que a família pode apresentar, afirma que "as especificidades ocorrem segundo a demanda e as características da família” (Elsen, 2002, p.18). Desta forma, a autora afirma que o cuidado é entendido e vivido de diversas maneiras, dependendo da necessidade e recursos disponíveis para cada grupo familiar. É com este olhar que nós voltamos para a família, tendo como elemento principal nesta relação, o cuidado.

\section{4. \\ Proteção Social X Cuidado}

Acreditamos ser importante abordar algumas maneiras de pensar proteção, por isso, iniciaremos esta seção com uma descrição de elementos históricos do que seja proteção social, a fim de traçar um panorama em relação ao assunto.

Podemos afirmar que não encontramos sociedade em que a preocupação com os membros mais vulneráveis não tenha sido pensada e que um sistema para tentar proteger tais membros não tenha sido desenvolvido. Existem diferenças tanto históricas como culturais de conceber Proteção Social e as questões que produzem a necessidade desta proteção. Para o sociólogo francês Robert Castel (2000), "Do ponto de vista histórico a questão social vincula-se estreitamente à exploração do trabalho" (Castel, 2000, p.416). Segundo Castel, a partir do século XIX, quando os trabalhadores começam a reagir contra a exploração de seu trabalho é que a questão social começa a ser pensada e formas de proteção da sociedade, colocadas em pauta.

No início da Revolução Industrial, a população que trabalhava no campo migra para as cidades e, com o grande contingente de trabalhadores chegando às capitais, enfrentam situação extremamente precária de sobrevivência. Neste contexto, sua força de trabalho é explorada fazendo com que o ritmo de trabalho seja intenso e, em contrapartida, seus direitos reduzidos. Deste modo, os trabalhadores começam a se organizar em sindicatos reivindicando condições mais justas de trabalho e proteção social, evidenciando as desigualdades geradas pelo sistema capitalista de produção. Aos poucos, o Estado começa a criar mecanismos 
de garantia dos direitos dos trabalhadores. Ainda seguindo o pensamento de Castel (2000),

É a partir do reconhecimento, do valor do trabalho e da organização da sociedade salarial que vai se constituir a moderna Seguridade Social, com garantias contra os principais riscos da existência como, por exemplo, a doença, a velhice sem pecúlio, acidentes e contingências. (Castel, 2000, p.445).

Assim, o Estado passa a garantir o bem-estar dos cidadãos, permitindo que tenham acesso aos bens e serviços necessários a uma vida mais digna. Castel (2005) define proteção social como "condição para construir uma sociedade de semelhantes: um tipo de formação social no meio da qual ninguém é excluído" (Castel, 2005, p. 58).

Tal tentativa de diminuir as desigualdades sociais e garantir direitos básicos aos trabalhadores que necessitassem começa a ser questionada, especialmente a partir da crise de 1970. Com a instabilidade do emprego, o Estado como garantidor do bem-estar social passa por modificações. Uma delas são as denominadas políticas de inserção, que pelo viés de Robert Castel (1998) “obedecem a uma lógica de focalização e de discriminação positiva focalizando os programas sociais nos segmentos mais empobrecidos da população" (Castel, 1998, p.422). Tal maneira de funcionar é observada ainda atualmente, em que percebemos a busca de proteção social através de políticas públicas basicamente pela camada pobre da população, disseminando a ideia de que tal proteção é exclusiva para os pobres e não algo que deveria complementar o não atingido através do mercado, isto é, não é uma política vista como igualitária mas voltada para os pobres e que apenas perpetua sua condição de dependentes devido ao caráter assistencialista e paternalista muitas vezes observado.

A desconstrução do Estado de Bem Estar Social ou Walfare State revela a impossibilidade de haver, como afirma o historiador Pierre Rosanvallon (1981), um "capitalismo democrático", em suas palavras: existe uma "incompatibilidade de uma conexão durável entre dinâmica capitalista, supressão de pobreza absoluta e redução de desigualdades" (Rosanvallon, 1981, p.147). Tal estudioso julga impossível haver conjugalidade entre um Estado de Bem Estar para todos com o sistema capitalista, visto que este é mantido pelo acúmulo de capital por parte de pequeno segmento da sociedade, gerando cada vez mais desigualdades sociais. 
O sistema de proteção é seletivo, pois os trabalhadores pertencentes ao setor formal, com carteira assinada, possuem direitos garantidos, como repouso remunerado, férias, regulação da jornada de trabalho. Por outro lado, os do setor informal são relegados à filantropia, dependem da sociedade civil para ter seus direitos atendidos. Abordando o contexto brasileiro, Sposati (1994) afirma que

O sistema protetivo brasileiro, se dualiza: de um lado, desenvolve-se fortemente apoiado na capacidade contributiva dos trabalhadores, particularmente do mercado formal de trabalho, e de outro vai destinar aos mais pobres, trabalhadores de um mercado informal, um "modelo de regulação pela benemerência" (Sposati, 1994, p. $8)$.

Desta maneira, percebemos a carência de uma política que realmente abarque os pobres e marginalizados, em que ações sociais sejam criadas e efetivamente disponíveis a toda população, sem cairmos na tentação de desenvolver estratégias assistencialistas e paternalistas somente perpetuando a condição de dependentes.

Corroborando com tal ideia, temos a afirmação do assistente social Ademir Alves da Silva (2004) a respeito dos serviços oferecidos, "Trata-se de manter um padrão mínimo de vida para todos os cidadãos, como questão de direito social, através de um conjunto de serviços provisionados pelo Estado, em dinheiro ou em espécie” (Silva, 2004, p. 56). Ou seja, a questão deixa de ser problema somente do sujeito e passa a ser também de responsabilidade social.

Segundo a Constituição Federal, criada em 1988, em seu artigo 227 a respeito da criança, do adolescente e da família, estipula que:

É dever da família, da sociedade e do Estado assegurar à criança, ao adolescente e ao jovem, com absoluta prioridade, o direito à vida, à saúde, à alimentação, à educação, ao lazer, à profissionalização, à cultura, à dignidade, ao respeito, à liberdade e à convivência familiar e comunitária, além de colocá-los a salvo de toda forma de negligência, discriminação, exploração, violência, crueldade e opressão. (Constituição da República Federativa, 1988, art.227).

Deste modo, deixa claro que o cuidado para com seus membros cabe, não somente à família, porém quando esta não dispõe de recursos suficientes para prover tal cuidado, o Estado deverá intervir de forma a auxiliá-la. Ideologicamente, seria uma função conjunta da família, sociedade e Estado, porém não é este panorama que observamos em nosso dia-a-dia. 
Dentro do contexto neoliberal como vimos, o Estado legitima sua função assistencial criando programas para atender a camada empobrecida da população. Todavia, o foco não é combater a desigualdade social crescente, porém criar programas para enfrentar a pobreza. Como muitas vezes não consegue atender à enorme demanda ou até pretende não haver necessidade de dar suporte a alguns grupos, delega à sociedade, especialmente às famílias, a função que deveria cumprir. Segundo afirma a pesquisadora Sonia Draibe a respeito do Estado Mínimo, "O mercado constituindo o melhor e mais eficiente mecanismo de alocação de recursos, a redução do Estado (do seu tamanho, do seu papel e de suas funções) é o mote e o móvel dessa ideologia..." (Draibe, 1993, p.89).

Desta forma, o Estado se exime da responsabilidade social, provendo o mínimo às pessoas que necessitam, contando com a participação de empresas privadas e das famílias para complementar o cuidado que não consegue prover. José Paulo Netto (2007) corrobora com esta ideia e escreve em seu artigo 'Desigualdade, Pobreza e Serviço Social' que os programas voltados para a pobreza dentro do contexto neoliberal, são caracterizados pela

[...] desresponsabilização do Estado e do setor público, concretizada em fundos reduzidos, corresponde à responsabilização abstrata da 'sociedade civil' e da 'família' pela ação assistencial; enorme relevo é concedido às organizações não governamentais e ao chamado terceiro setor”. (Netto, 2007, p.159).

Com a responsabilidade de suprir as necessidades dos sujeitos, as famílias precisam fazer um verdadeiro malabarismo para cumprir com tal responsabilidade, pois na maior parte das vezes não dispõem de recursos mínimos para dar conta integralmente da demanda. Assim, não raro pré-julgamos certas situações que à primeira vista poderíamos pensar se tratar de negligência, porém quando analisamos os fatos, percebemos que se há negligência esta é relativa ao Estado por não auxiliar a família a cumprir com seu dever de cuidar de seus membros.

Todavia, se como profissionais não estivermos atentos a esta conjuntura, podemos tomar decisões precipitadas onerando ainda mais as famílias já colocadas à margem da sociedade e contribuindo para a continuação deste sistema de mercantilização das políticas públicas e a precarização dos serviços oferecidos.

Discutimos a respeito de proteção social para a garantia do bem-estar porque acreditamos ser relevante fazermos distinção entre proteção e cuidado, porém o que 
nos interessa enfocar na presente pesquisa é o conceito de cuidado sob a dimensão epistemológica. Desta forma, no decorrer do próximo tópico abordaremos tal conceito dentro da perspectiva que nos interessa discutir. 


\section{3 \\ Cuidado: o que é afinal?}

\section{1.}

\section{A gênese do Cuidado}

Com o progresso do conhecimento científico passado de geração em geração, o homem foi se modificando e o cuidado o acompanhou. Desta maneira, a vida humana introduziu e integrou continuamente esses novos saberes. Data de milhões de anos o início da vida na Terra, porém acerca de 70 milhões de anos, uma catástrofe destruiu todos os grandes animais e, de acordo com o sociólogo italiano Domenico de Masi (2003), configura- se nessa época o começo da formação dos ancestrais mais longínquos dos animais atuais e dos precursores dos macacos. A partir de então, as espécies seguiram sua própria evolução, aperfeiçoando-se e desenvolvendo-se (De Masi, 2003).

O primeiro período dessa história, que terminou somente há 9 ou 10 mil anos, é denominado paleolítico e nele o homem passou de Australopithecus a Homo habilis e de Homo erectus a Homo sapiens. Inicialmente, os bandos humanos eram nômades, permanecendo temporariamente em determinado local até a exaustão de recursos naturais, quando, então, se dirigiam em busca de outras novas fontes de alimentação. Segundo estudo realizado pelo zoologista inglês Morris (1977), os primitivos eram uma extensão do seu meio ambiente, estavam imersos em seu habitat, mas não se pode afirmar que o dominavam. Viviam em árvores, o que lhes garantia, ao menos provisoriamente, alimentação e resistência às investidas dos animais. Como a alimentação era abundante, os bandos não precisavam se separar para procurar comida; eles moviam-se, descansavam e dormiam juntos, em uma comunidade onde cada integrante podia observar as ações e os movimentos do outro. Mesmo se afastando de tempos em tempos, nunca havia unidades constituídas por um só indivíduo, o que aumentava sua vulnerabilidade (De Morris, 1977).

No denominado primitivismo, o homem moldava-se através de suas interações com os outros membros de seu grupo social, vindo a transformar-se em 
um ser ético. Valorizava tanto a cooperação quanto a dependência de seus semelhantes e depreciava a agressividade e a autossuficiência, gerando uma estabilidade social. Estes valores, então, determinavam a sobrevivência e o conforto do indivíduo, além de uma estabilidade de caráter dependente da satisfação moral, que juntas mantinham as relações entre os companheiros, vantajosas para todos. As fragilidades individuais expostas ao ambiente hostil, juntamente com a precariedade estrutural dos objetos para sua defesa, fizeram com que houvesse um despertar na socialização do homem, transformando suas necessidades individuais em coletivas. A partir de então, ainda sob o viés de Morris, parecem ter resultado a organização das relações tribais e a concepção específica da experiência coletiva.

Complementando esta ideia, segundo o antropólogo Lewis (1968), nesta época, o indivíduo era secundário ao grupo, uma vez que a vida social oferecia proteção e ajuda recíproca. Os modelos de comportamento eram introduzidos no grupo, tanto como instintos sociais quanto hábitos sociais, passando a fazer parte da herança transmitida e sendo fundamentais para a sobrevivência. Estes comportamentos eram o cimento da comunidade, tratando de moldá-la e preservála, pois cada sujeito, inconscientemente, postulava "[...] a sua própria existência na continuidade do grupo porque, na luta pela sobrevivência não havia outra possibilidade de existir" (Lewis, 1968, p. 40). Assim, o profundo instinto de autopreservação estava intrinsecamente ligado ao sentimento comunal.

Algumas alterações morfológicas tornaram os primitivos aptos à caça, como a posição ereta, que os fez caminhar mais rapidamente deixando as mãos livres para a apreensão das presas e para empunhar armas para atacá-las. A invenção do arco e da flecha tornou a caça uma atividade regular e costumeira, mas o grande progresso do homem nesse período foi expresso pela formação da linguagem articulada. A fabricação de armas e instrumentos utilitários de pedra foi essencial para a sobrevivência humana, sendo que para tal o homem devia reconhecer as melhores pedras. Da mesma maneira, para caçar ele tinha que dominar elementos de zoologia e para apanhar frutos era importante que ele possuísse alguma iniciação em botânica, o que lhe proporcionava uma gama de conhecimentos bastante ampla, que era transmitida aos seus descendentes. O homem controlou o fogo, e emancipou-se do seu ambiente natural, pois não dependia mais somente do sol para iluminar os seus caminhos e para lhe aquecer. Com o fogo, passou a dominar os animais, a cozinhar certos alimentos e, acima de tudo, passou a controlar sua força física, 
fazendo com que se afastasse definitivamente do "comportamento dos outros animais, afirmando sua humanidade" (Lewis, 1968, p. 63).

Voltando ao pensamento de Morris (1977), com o passar do tempo, os humanos tornaram- se sedentários satisfazendo sua necessidade de abandonar os caminhos sinuosos e nômades de seus antepassados para ter uma base fixa, "um local para onde trouxesse os despojos, onde se mantivessem as fêmeas e as crias e onde pudessem partilhar a comida" (Morris, 1977, p. 68). Complementando esta ideia, Childe (1978) afirma que a fixação dos grupos humanos trouxe o desenvolvimento de uma cultura grupal, em que se destacavam as atividades agrícolas e pastoris. Estes grupos eram autossuficientes economicamente, apesar de desenvolverem uma forma rudimentar de comércio. A economia doméstica estava baseada no comunismo, que abarcava várias famílias, sendo que tudo era realizado e utilizado em comum, como a casa, as canoas e as hortas.

Inicialmente, as trocas, de objetos e víveres, parecem ter ocorrido entre os agricultores sedentários e alguns grupos seminômades, como pescadores, caçadores e pastores. Entretanto, a domesticação de animais e a criação de gado, como mananciais de riqueza, otimizaram novas relações sociais, favorecendo a primeira grande divisão do trabalho pelo intercâmbio regular de melhores e mais diversificados produtos entre membros de tribos diferentes. O gado, como mercadoria, nesse período, desempenhou as funções de dinheiro (Childe, 1978).

O desenvolvimento de outros ramos da produção, além da criação de gado, como a agricultura, ofícios manuais domésticos, “[...] tornou a força de trabalho do homem capaz de produzir mais do que o necessário para sua manutenção, ao mesmo tempo em que aumentou a soma de trabalho diário correspondente a cada membro da comunidade doméstica ou da família isolada (Childe, 1978). Com isso, passou a ser necessária mais força de trabalho, que foi obtida através das guerras e consequente aprisionamento dos inimigos, tornados escravos. A superioridade masculina, nesse período, foi configurada pela propriedade privada dos instrumentos de trabalho e da produção obtida através deles. A divisão social do trabalho na família continuava sendo a mesma, mas acabou por transformar as relações domésticas, uma vez que a divisão do trabalho fora da família havia mudado. 
Assim, o matriarcado, que até então marcava as relações, cedeu lugar ao patriarcado e à formação da família monogâmica, em lugar da sindiásmica ${ }^{8}$. A segunda divisão social do trabalho não tardou a ocorrer, pela variedade e aperfeiçoamento da produção e o enriquecimento individual, fazendo com que houvesse a separação entre o artesanato e a agricultura. Este crescimento da produção, ligado ao aumento da força de trabalho, proporcionou o incremento da força de trabalho do homem, tornando a escravidão elemento básico do sistema social. Assim, além da diferença já existente entre homens livres e escravos, consolidou-se a diferença entre ricos e pobres, acarretando uma nova divisão da sociedade em classes. Estas sociedades se organizavam também em grupos não parentais e os utilizavam como uma maneira de tornar a vida mais movimentada, esses grupos agregavam indivíduos de mesmo sexo ou idade, mas sua origem podia estar vinculada à experiência ou habilidade comum. Geralmente eram recreativos e promoviam festas, bailes e estavam incorporados ao trabalho ou em cerimoniais, prestando funções importantes ao bem-estar de toda a sociedade. As associações tribais não eram totalmente voluntárias, visto que algumas reuniam somente adultos de mesmo sexo (fraternidade tribal), outras se restringiam a homens e mulheres em determinada faixa etária (grau de idade ou conjunto de idade) e outras, ainda, eram formadas por indivíduos com habilidades especiais ou riqueza. O parentesco e o local onde se localizavam podiam, também, configurar a filiação. As mulheres possuíam uma vida clubista pouco desenvolvida, pois se dedicavam à reprodução e à casa.

Esta situação ocorria devido ao domínio masculino, uma vez que os homens desestimulavam qualquer participação feminina nos clubes organizados por eles e não achavam interessante que as mulheres os imitassem, especialmente que soubessem de seus rituais secretos, particularmente aqueles dedicados à religiosidade. Nas sociedades tribais havia ritos de iniciação tanto masculinos como femininos e o sexo oposto era sempre excluído dessas cerimônias.

\footnotetext{
${ }^{8}$ A família sindiásmica é um dos modos organizativos que teve a família na evolução da sua história, com determinadas características particulares, a partir da sua origem. Segundo Engels, essa forma de família é caracterizada pelo matrimônio por pares, embora a poligamia e infidelidade sejam encaradas como direito dos homens. Em contraposição, a fidelidade era exigida de forma rigorosa das mulheres, sendo o adultério duramente castigado (ENGELS, 1981).
} 
Desta maneira, assim como representou um período de inúmeras transformações morfológicas e sociais do homem, o paleolítico também conteve muitas práticas de cuidar, que foram se especializando tanto quanto as atividades humanas. Historiadores e antropólogos consideram que a proteção materna instintiva foi a primeira forma de manifestação do cuidado humano (Donahue, 1985). Igualmente, pode-se afirmar que o cuidado, nesta época, estava ligado à economia de subsistência, inserido em um sistema de trocas, além de depender da solidariedade, do inter-relacionamento e da interdependência de homens e mulheres em um reconhecimento mútuo do trabalho.

Além disso, em um primeiro estágio, as práticas de cuidar restringiam-se a medidas higiênicas, uma vez que os conhecimentos sobre a saúde, modos de amenizar os males físicos, suprimir as dores eram dirigidos basicamente para a sobrevivência. Estas práticas, além de instintivas, parecem ter sido aprendidas através da observação dos animais que ocupavam o mesmo habitat do homem. Assim, lavar as feridas, lamber partes do corpo, refugiar-se do frio, utilizar plantas, entre outros costumes, foram copiados pelo homem dos animais.

Mais adiante, os problemas de saúde eram tratados por feiticeiros, pajés ou sacerdotes, uma vez que esses eram reconhecidos pelos seus dotes especiais. Não havia uma clara divisão do trabalho na saúde, já que uma mesma pessoa exercia as funções relativas ao diagnóstico, à terapêutica e ao tratamento, podendo ter ajuda de um aprendiz. As doenças e a terapêutica destinada a elas eram explicadas pelo pensamento mágico-místico que dominava essa época. Assim, o cuidado ao outro, em condição de saúde ou doença, modificou-se na história, acompanhando as mudanças sociais e culturais dos grupos humanos. Em um primeiro momento, o cuidado foi desenvolvido de modo singular, instintivo, e, aos poucos, foi sendo institucionalizado, demonstrando, sempre a necessidade que o ser humano possui de ser cuidado e de cuidar. 


\section{2. Elementos que podem contribuir para a definição de cuidado}

Conforme relatado no início do estudo, houve uma busca inicial para refletirmos sobre como o cuidado era abordado por diferentes autores e áreas de conhecimento. Observamos que, na grande maioria dos trabalhos, senão em todos, o cuidado é abordado como prática e/ou é atribuído caráter ontológico ao mesmo. Como a proposta da pesquisa é elencar elementos que possam contribuir para a definição de cuidado, utilizamos os estudos realizados para inferirmos os elementos que aparecem com frequência.

Segundo o dicionário Houaiss da Língua portuguesa (2001), cuidado pode ser empregado como substantivo ou adjetivo e é definido como:

Atenção; em que há cautela, prudência.

Esmero; aplicação e capricho ao realizar algo.

Preocupação; atenção maior em relação a: ele necessita de cuidados.

Responsabilidade; dever de arcar com seus próprios comportamentos ou com as ações de outrem: cuidados médicos.

O que é alvo dessa responsabilidade: eles estão sob seus cuidados.

Aprimorado; muito bem-feito; em que há primor, capricho.

Ponderado; sobre aquilo que se pensa em excesso.

Calculado; que foi previsto; muito ponderado: teve uma intenção.

Tratado; que foi ou tem sido alvo de um algum tipo de tratamento especial.

A partir destas definições, que sob nosso ponto de vista mais parecem características atribuídas ao cuidar, do que propriamente definições de cuidado, podemos relacionar as variadas maneiras de abordar o cuidado e os elementos que devem compô-lo.

É interessante notarmos, que assim como o entendimento de família, cuidado tem história e geografia, ou seja, muda no tempo e espaço. Ainda fazendo um paralelo com o conceito de família, o consideramos uma construção social, formado 
a partir de valores culturais. Assim, o que algumas culturas em um determinado período de tempo acreditam ser cuidado, para outras pode significar omissão ou até mesmo violência. Em algumas tribos africanas, por exemplo, as filhas são iniciadas sexualmente pelos parentes, prática ainda observada nos dias atuais, significando sua entrada ao universo dos adultos (Gonçalves, 2003).

Com base nos estudos realizados por Boff (2011), podemos afirmar que para ele cuidado é um modo de ser em que a pessoa sai de si e centra no outro com desvelo. Deste modo, entendemos que cuidado implica estar atento ao outro e às suas necessidades, demonstrando interesse e preocupação. Quando ele afirma que "Se ao largo da vida, não fizer (o ser humano) com cuidado tudo o que empreender, acabará por prejudicar a si mesmo e por destruir o que estiver à sua volta" (Boff, 2011, p.34), podemos dizer que além da atenção, preocupação e interesse no outro, cuidado implica respeitar o próximo. Outro elemento bastante importante em sua obra a respeito do cuidado, é a preservação pois é através das relações interpessoais e da relação do sujeito com o mundo ao seu redor, que a pessoa irá se construindo e dando continuidade a tudo o que existe.

A preservação também aparece nos estudos de Foucault (2006), porém como para o estudioso o cuidado deve ser voltado primeiro para si mesmo, pois somente após estarmos cuidados é que estaremos aptos a cuidar do outro, a preservação assume um sentido de autopreservação. A pessoa, no caso do âmbito familiar, aquela responsável por cuidar de seus membros, em um primeiro momento precisaria se distanciar do outro e focar no cuidado de si mesma, refletindo a respeito de suas responsabilidades e possibilidades, para depois agir em relação ao outro. Isto contribuiria para a preservação do cuidado e, portanto, da espécie humana.

Neste ponto, faremos uma ligação entre a autopreservação em Foucault e a segurança, sob a ótica de Winnicott (1999). A nosso ver, esta seria outro elemento importante no cuidado. Segundo este autor, a família teria papel fundamental no atendimento às necessidades de seus membros e, estas necessidades devem ser entendidas como físicas, sociais e afetivas. No que diz respeito às necessidades físicas, destacamos o abrigo, o alimento e a segurança como elementos principais. Além disso, é preciso atender as necessidades afetivas, que incluem sentimento de pertencimento, amparo e proteção. 
Como vimos anteriormente nesta pesquisa, mas vale revisitarmos, é a posição de Winnicott (1971) em relação ao desenvolvimento das potencialidades do ser humano. Para ele, toda pessoa teria potencial inato para amadurecer e se desenvolver, porém isto só ocorrerá com um ambiente facilitador que atenda às necessidades da criança. Cada família, então, buscará oferecer o melhor possível ao desenvolvimento de seus membros e este crescimento dependerá em grande parte também do próprio sujeito e o que é capaz de conseguir naquele momento, frente àquela experiência singular.

Seguindo este pensamento, temos os estudos realizados por Bowlby (1990), em que assegura que os seres humanos apenas serão capazes de se desenvolver quando estiverem seguros de que existem pessoas ao seu redor prontas a ajudar caso surjam dificuldades. Podemos então observar, que mais uma vez a segurança aparece como elemento de cuidado, pois somente em contato com pessoas que transmitam segurança a criança conseguirá desenvolver suas potencialidades.

Ainda segundo Bowlby, outro elemento que podemos entender como pertencente ao cuidado é o vínculo, ou seja, "qualquer forma de comportamento que faça com que uma pessoa alcance ou conserve a proximidade de outro indivíduo diferenciado e preferido" (Bowlby, 1990, p.56).

Corroborando com esta ideia, Maranhão (2000) trata o cuidado como uma atividade relacional originada a partir dos desejos de quem cuida, atribuindo necessidades ao objeto do seu cuidado de acordo com o sentido que o cuidado tem para ele/a. Então, podemos observar que mais uma vez a criação de vínculos aparece como elemento de cuidado, pois acredita que é necessária uma interação entre quem cuida e quem é cuidado.

Além disso, Maranhão acredita que estes vínculos precisam estar em conformidade com o contexto sociocultural em que os sujeitos estão inseridos. Assim como Winnicott, a autora afirma que o desenvolvimento da pessoa dependerá, não somente de suas potencialidades, mas também do contexto em que está inserida. E este, pelo nosso entendimento, seria mais um elemento que deveria compor cuidado.

Seguindo o gancho do contexto social, no decorrer da próxima seção abordaremos as relações de gênero, geração e classes sociais dentro dos contextos sociais e históricos. 


\section{3.}

\section{Cuidar: uma questão de gênero?}

Como temos observado no decorrer do presente estudo, a divisão de trabalho entre homens e mulheres acompanha a história desde tempos remotos. Vimos que nos primórdios da história da espécie, nossos ancestrais praticavam um modo de vida nômade, baseado na caça e na coleta, no qual cabiam aos homens a obtenção de carne e a defesa do grupo, e às mulheres a coleta de frutos, folhas e raízes, o processamento dos alimentos coletados e, além disso, o cuidado dos filhos pequenos.

Quando passamos às sociedades agricultoras, outros fatores entram em ação e devem ser considerados. Afinal, a complexidade das relações sociais não se restringe ao tema do trabalho, mas envolve, sobretudo, a análise a partir da produção/reprodução dos aspectos da vida social. Segundo Engels (1981), a revolução agrícola produziu transformações radicais no relacionamento entre os sexos e no lugar social da mulher: a sedentarização, correlata necessária da agricultura devido à espera pela colheita, cria a propriedade e com ela a herança, a partir da qual vem a necessidade da certeza de paternidade e, portanto, a exigência da virgindade pré-nupcial e da fidelidade feminina pós-nupcial. Posteriormente, cria a necessidade de um Estado regulador das relações de propriedade e de outras relações sociais. Nessas circunstâncias, o trabalho feminino tende a ser confinado aos lares, onde a mulher está mais "protegida", restrita às atividades reprodutivas e domésticas.

Outro aspecto interessante que compõe esse novo modo de vida é a transformação nas estratégias de reprodução. Nas sociedades de caça e coleta, os nascimentos são espaçados no mínimo em três ou quatro anos, para viabilizar a criação bem-sucedida de cada bebê. Entretanto, no modo de vida agrícola, mais filhos e, de preferência do sexo masculino, representam mais força de trabalho nas roças ou no pastoreio. Deste modo, passa a ser desejável que as mulheres tenham muitos filhos, mantendo-as quase que em estado contínuo de gestação. Ainda sob a perspectiva de Engels (1981), 
O fato que dentre os 20 ou 25 filhos nascidos de uma mesma mãe, nesse regime, um número significativo não sobreviverá, bem como a própria incidência alta de mortalidade feminina associada ao parto, são minimizados como fenômenos naturais. Esse descaso pela mortalidade infantil e materna vai acompanhar boa parte da história humana pós-agricultura. (Engels, 1981, p.152).

Certamente, ao longo da história das sociedades humanas, há diversos graus de confinamento e de restrição às atividades produtivas e sociais da mulher. Existem diferenças entre os segmentos socioeconômicos: em camadas mais pobres, a participação da mulher na atividade rural não foi tão restringida, até pela necessidade de braços para o trabalho. A imagem que formamos da vida feminina refere-se principalmente às camadas privilegiadas, excluindo escravos e escravas, e também os homens e mulheres livres de condição social inferior.

De acordo com Bueno (1999), é provável que essa mesma diversidade, escondida sob os valores das classes dominantes que são os que geralmente nos chegam, tenha percorrido a história medieval e a história moderna anterior à Revolução Industrial. Além disso, mesmo entre nobres e cavaleiros, as esposas e/ou filhas, às vezes as irmãs na falta destas últimas, necessariamente assumiam pelo menos parte da responsabilidade pela administração da vida econômica da família, dadas as ausências frequentes e prolongadas dos homens. Um exemplo dessa situação, no século XVI, é a atribuição às esposas, pelos donatários de capitanias hereditárias no Brasil, de poderes sobre a propriedade durante suas ausências para guerras ou outras aventuras (Bueno, 1999).

Após mais de vinte e cinco séculos, se incluirmos a história das civilizações pré-cristãs, chegamos à segunda grande revolução no modo de vida das sociedades humanas: a Revolução Industrial. Mais uma vez, é impossível não notar diferenças entre as classes sociais em relação à participação da mulher no trabalho produtivo: o proletariado é composto de homens e mulheres, inclusive crianças; a discriminação fica por conta dos salários, sempre mais baixos, para mulheres e crianças, como ocorre até hoje em muitos setores; são as mulheres de classe média e alta que ficam confinadas e alijadas do trabalho produtivo, buscando a modelagem de perfis de distinção, de honra e de cuidadora do lar, da família e das futuras gerações.

Finalmente, durante as Grandes Guerras do século 20, e na fase de reconstrução que se seguiu a elas, a participação das mulheres no mercado de 
trabalho cresce exponencialmente, assim como sua penetração em setores e atividades tradicionalmente masculinos. Na década posterior à Segunda Guerra, a participação feminina no mercado de trabalho cresceu, principalmente em setores como serviços, escritórios, comércio e serviços públicos. Também se ampliavam as oportunidades nas áreas de saúde e educação, representando um aumento na exigência por qualificação e escolaridade (Silva, Nader \& Franco, 2006).

Para Delcor e Cols. (2004), a docência, assim como a enfermagem, foi considerada "atividade própria das mulheres por envolver o cuidado dos outros" (Delcor, 2004, p.189). As mulheres foram chamadas para ocupar os cargos de educadoras, considerando-se o trabalho na creche e na escola como uma continuação das tarefas exigidas no âmbito doméstico. Bomfim, Bastos e Carvalho (2007) relatam em seu estudo que, entre seis famílias nas quais um dos membros teve que ser internado em UTI (Unidade de Terapia Intensiva), apenas em uma família um cuidador do sexo masculino assumiu responsabilidade pelo acompanhamento do paciente, tratava-se de um viúvo que há anos, desde sua aposentadoria, já cuidava de toda a administração doméstica e da atenção aos filhos. Em outras dez famílias em que havia entre os filhos um paciente crônico (paralisia cerebral), e cujas mães recrutavam a ajuda de outros filhos para o atendimento ao irmão ou irmã, Soares (2005) relata que: nos casos em que o filho recrutado é do sexo masculino, ou só há irmãos do sexo masculino, ou ainda só há uma irmã, mais jovem do que eles (que também eram mais jovens do que o paciente a ser cuidado); nos casos em que meninas são chamadas a cuidar, pode haver irmãos mais velhos que não são recrutados; mesmo quando a irmã é mais jovem do que o paciente, e tem um irmão mais velho, é a irmã mais jovem a que a mãe solicita auxílio. Apesar das limitações desses dados em termos quantitativos, eles parecem sugerir uma atitude que leva as mães a preferirem entregar o cuidado do filho com necessidades especiais a uma irmã, a menos que não haja essa alternativa.

Além da permanência em áreas tidas historicamente como femininas, estudos mostram que a maioria dos cargos gerenciais ou executivos em empresas e no governo se mantêm sob responsabilidade de homens (Silva \& Cols, 2006). Em sua análise de sete empresas familiares, Almeida (2005) encontra apenas um caso em que o papel da mulher na empresa é compatível ao do marido em termos de responsabilidades financeiras e gerenciais; em todos os demais, o marido é o 
responsável pela administração financeira, enquanto a esposa cuida de aspectos do quotidiano e das relações pessoais dentro da empresa.

Por outro lado, se consideradas retrospectivamente, essas tendências documentam um crescente ingresso da mulher em campos de trabalho reservados anteriormente ao homem. Crescem também as proporções de mulheres no ensino superior, fenômeno acelerado quando se considera que datam de menos de um século os primeiros registros de matrículas femininas nesse nível de instrução.

Qualquer que seja o grau e tipo de participação da mulher no mercado de trabalho ao longo do processo histórico, mulheres tipicamente cumpriram e continuam a cumprir jornada dupla; os afazeres domésticos e o cuidado dos filhos ainda recaem sobre elas na grande maioria dos casos. Esta dupla jornada torna-se mais visível na sociedade urbana contemporânea, em que participar do mercado de trabalho quase sempre significa trabalhar fora de casa, com as complexidades que essa condição introduz no cuidado dos filhos e do lar.

Surge então a questão: A quem cabe o cuidado dos filhos na falta parcial ou total das mães, seja por contingências de trabalho ou por outros fatores? $\mathrm{O}$ abandono de crianças seja pela pobreza, condenação em relação às mães solteiras ou esfacelamento da família em relações escravagistas foi contornado, entre outras medidas, pela fundação de instituições religiosas como as Santas Casas de Misericórdia, que contavam com "mulheres criadeiras", religiosas ou funcionárias, que procuravam suprir a lacuna criada pela ausência materna e paterna. De acordo com um manual para criação de filhos do século XVII, de autoria de Alexandre de Gusmão, um dos fundadores de seminários jesuítas do Estado da Bahia, cabia à mãe a criação e ao pai a direção. "Durante os primeiros anos de vida dos bebês, todo trabalho pesava sobre a mãe. Assim, a que não assumisse os filhos quebraria as regras da vida social por comprometer a formação do futuro adulto" (Del Priore, 2001, p.201).

No mundo contemporâneo, esta ideologia rígida que levava até mesmo mães de famílias influentes a abandonarem filhos por pressões sociais tende a desaparecer, paralelamente às transformações na própria família, embora o abandono continue a ser um fato social, agora decorrente basicamente da pobreza (Carvalho, 2008). Nos estratos sociais mais privilegiados, tal como sempre ocorreu em fases históricas anteriores, tarefas domésticas e de cuidado das crianças são compartilhadas com babás, outros membros da família ou educadoras de creche em 
todos os casos, tipicamente, mulheres. Castro, Miranda e Almeida (2007) salientam que entre as transformações históricas da família incluem-se novas relações de gênero e com estas a desestabilização da figura do pai como lei e autoridade, mas apontam também que os homens continuam a desempenhar papel secundário no que se refere ao cuidado dos filhos e outras tarefas domésticas. Lembra ainda que a participação masculina nessas tarefas, além de limitada, é bastante seletiva, como evidenciam Araújo e Scalon (2003).

Ainda a respeito do estudo realizado por Araújo e Scalon (2003), encontram indícios de aumento da participação masculina em cuidado dos filhos, mas não em tarefas domésticas. Os resultados confirmam que, entre oito tarefas domésticas investigadas, apenas uma (pequenos consertos) apresentou participação masculina significativa (54\% de exclusividade na tarefa); no caso de cuidado das crianças, a participação masculina exclusiva não ocorreu em nenhuma das sete tarefas investigadas; o que aparece com maior frequência (30\% ou mais), segundo declarado pelos pais, é a participação conjunta com a mãe em brincar, levar ao médico, colocar para dormir, acompanhar tarefas escolares e levar/pegar na escola, mas, nas declarações de mães, apenas brincar (pai e mãe juntos) ocorre em mais de $20 \%$ das respostas.

Jablonski (2007) identifica a profunda alteração nos papéis de gênero tradicionais em decorrência do ingresso das mulheres no mercado de trabalho, levando a crer em maior igualdade ou flexibilidade desses papéis. Entretanto, reconhece que, ainda que existam alguns indicadores de maior participação masculina em atividades relacionadas aos filhos, o mesmo não ocorre em relação a tarefas domésticas. Apesar das mudanças culturais, em seu estudo qualitativo com oito casais, verifica que "parece ainda persistir uma visão conservadora dos papéis dos cônjuges no que se refere às tarefas domésticas e à responsabilidade pelo cuidado e educação dos filhos" (Jablonski, 2007, p.209). As práticas dos homens nessas tarefas aparecem como coadjuvantes e complementares em relação às das mulheres. Essas observações são corroboradas por Rocha-Coutinho (2003), em pesquisa qualitativa com 12 mulheres executivas cariocas entre 25 e 45 anos. Seus resultados indicam a manutenção dos papéis de gênero, com participação periférica dos homens nas tarefas domésticas enquanto as mulheres tentam conciliar trabalho extra doméstico e família. 
Esses e outros trabalhos indicam que, ao mesmo tempo em que as mulheres se mostram aptas a desempenhar funções tradicionalmente masculinas no âmbito do mercado de trabalho, a maioria dos homens ainda não assumiu o desempenho de tarefas tradicionalmente femininas, principalmente as de cuidado, e só as desempenham quando isso ocorre de forma complementar ou auxiliar em relação à mãe ou outras figuras femininas (Torres, 2004).

Refletindo sobre estas evidências, percebemos que durante boa parte da história ocidental, pelo menos em culturas cujas religiões deixavam espaço para a atuação social feminina, mulheres foram responsáveis pela ministração de cuidados médicos, especialmente no que se refere ao parto. Este lugar passa a ser negado à mulher conforme a medicina se torna institucionalizada como saber e é apropriada pelos homens (Spink,1982).

O saber a respeito da cura foi tratado como feitiçaria durante a Idade Média e levou muitas mulheres à fogueira. Curar e cuidar parecem ter sido historicamente separados, restando à mulher papéis complementares do cuidado com a saúde, ao passo que aos homens se atribuíam os papéis mais valorizados de detentores do saber médico.

Para refletirmos a respeito do assunto, recorremos a duas linhas de pensamento; uma que afirma que a diferença de gênero nas formas de cuidar possui um enfoque biológico e outra, que sustenta ser a cultura a responsável pelas diferenças entre homens e mulheres em relação à predisposição e competência para o cuidado.

Segundo Rodrigues (1998), o enfoque biológico considera a evolução parental como evento chave do surgimento da sociabilidade na classe dos vertebrados. O aparecimento dos sinais envolvidos na relação pais-filhos, as solicitações infantis e as respostas afetivas dirigidas aos filhotes criaram condições para o desenvolvimento de relações amigáveis e afetivas dos adultos. O aparecimento do cuidado parental se constituiu em um momento crítico na evolução comportamental dos vertebrados e insetos superiores. A evolução do estabelecimento de vínculos entre indivíduos começou com o cuidado parental e marcou o segundo momento decisivo na evolução dos vertebrados. Sendo o homem um primata, a reflexão sobre o cuidado parental humano, tal como de outros animais, deve levar em consideração a análise do investimento parental de um ponto de vista funcional e evolutivo. A estratégia humana original de reprodução, segundo 
este enfoque, é o nascimento de poucos filhotes e grande investimento parental e/ou grupal em cada filhote. $\mathrm{Na}$ análise comparativa entre os gêneros, essa tese sugere, no caso do ser humano, que a mulher seria mais predisposta ao cuidado dos filhos, com base no argumento funcional e evolutivo de que seu investimento parental é maior do que o do homem.

Surge, deste modo, a questão: O que é investimento parental? No ambiente humano de evolução, além dos nove meses de gestação, a criação bem-sucedida de um filho envolve longos meses de amamentação e atenção constante para a proteção dos bebês, que deviam ser carregados nas excursões de coleta de alimento. Em sociedades de caça e coleta, possivelmente o melhor modelo de que dispomos sobre o ambiente em que se processou a evolução humana, esse investimento significava e ainda significa, nas sociedades remanescentes, três a quatro anos de vida da mãe que se expressam, como vimos acima, no espaçamento entre nascimentos típico dessas sociedades, e em um número limitado de filhos por mãe, lembrando que a expectativa média de vida não ultrapassava 40-50 anos, sendo otimistas.

Nestas condições, a perda de um filho é um custo evolutivo, em termos de sucesso reprodutivo ou transmissão de seus genes para a geração seguinte, muito mais alto para a mulher do que para o homem, que pode produzir descendência com diversas mães e pouco investimento. Seria de esperar, portanto, uma especialização maior da mulher do que do homem nas tarefas de cuidado parental. Supõe-se, para complementar a hipótese, que a predisposição cuidadora poderia se generalizar para outros parceiros sociais além dos filhos, tais como idosos e parentes sozinhos.

Ao contrário do que geralmente se acredita, a hipótese do investimento parental não requer determinismo genético ou manifestações comportamentais imunes ao ambiente. Implica antes, como qualquer manifestação do potencial genético, em encontro e interação com um ambiente que permita esta manifestação.

Tudo o que os seres humanos são ou fazem (ou que outros animais são ou fazem), tudo o que tem a ver com nossos corpos, nossas mentes e nosso comportamento, decorre da ação conjunta de hereditariedade e ambiente. Nada poderia se desenvolver sem os genes e nada poderia se desenvolver sem um ambiente adequado.

Assim, por exemplo, as pré-adaptações para o apego mãe-filho (que pode também ser pai-filho, ou avó-neto, mas depende sempre de uma troca social individualizada) só podem se expressar se os bebês tiverem oportunidade de 
interação com a mãe ou outros adultos nos primeiros meses ou anos de vida. A construção de relações depende da oportunidade de trocas sociais concretas na interação quotidiana. Em condições habituais, da vida humana, esta oportunidade é maior entre mãe e filho (a) do que entre outros adultos e o bebê. Além disso, a literatura das últimas décadas a respeito de competências do recém-nascido e de interação mãe-filho ${ }^{9}$ no início da vida evidencia a existência de um ajuste biológico muito fino no sentido de favorecer essa ligação. As diferenças culturais quanto ao envolvimento de mães e pais na criação de filhos não deveriam, portanto, obscurecer a percepção das regularidades: mães tipicamente assumem responsabilidade maior pelo cuidado e nutrição das crianças pequenas, enquanto pais se responsabilizam por outras esferas.

Outro argumento que vem ao encontro da hipótese do investimento parental e da decorrente superioridade feminina nas tarefas de cuidado deriva de estudos de interação criança-criança. Em uma revisão enfatizando os estudos sobre comportamento de cuidado entre crianças, Lordelo e Carvalho (1989) encontraram diversas indicações de prevalência e predisposições do sexo feminino para este tipo de comportamento em diferentes situações. Meninas parecem mais orientadas para bebês, obtêm escores mais altos em diversas medidas de empatia, apresentam mais fala maternal (baby talk) e envolvem-se mais em ações de cuidado físico, tais como limpar, pentear, trocar fraldas, na interação com bonecos. Em seu próprio estudo, Lordelo e Carvalho, observando grupos de crianças de 5 a 80 meses em atividade livre, sem intervenção ou orientação de adultos, encontraram diferenças a favor de meninas nas categorias denominadas mimar e cuidar fisicamente, enquanto a maior parte das interações de meninos se situaram na categoria ensinar; nos dois casos, os comportamentos que podiam ser caracterizados como cuidar dirigiam-se preferencialmente a crianças mais jovens.

Outro indicador possível é a incidência de famílias chefiadas por mulheres, especialmente em estratos socioeconômicos mais baixos, mas também em estratos médios e superiores. Segundo dados do Instituto Brasileiro de Geografia e Estatística de 2000, um quarto das mulheres brasileiras que trabalham são chefes de suas famílias, sendo que $30 \%$ delas se encontram abaixo da linha da pobreza (Cavalcanti, 2005). Homens parecem ter mais facilidade de se afastar da família e

\footnotetext{
${ }^{9}$ Como, por exemplo, os trabalhos de Bowlby (1990), citado anteriormente neste estudo.
} 
dos cuidados parentais, o que é compatível com o menor investimento parental masculino. Mulheres com frequência assumem todos os encargos da parentalidade, associando tarefas de sustento e tarefas de cuidado, com maior ou menor sucesso. Ainda sobre esse tópico, as estatísticas a respeito de divórcio e re-casamento sugerem que homens raramente assumem as tarefas quotidianas de cuidado, em geral voltando a se casar, enquanto entre mulheres é mais comum o acúmulo de papéis de cuidadora e de provedora e a manutenção do status de separada.

A interpretação deste tipo de indício é complexa. Embora todos os indícios alegados acima sejam compatíveis com a hipótese biológica do investimento parental, e da maior dotação feminina para o cuidado do outro, também é possível interpretá-los segundo uma concepção culturalista, em que a ideologia, as práticas correntes e outros fatores culturais relativamente arbitrários seriam os responsáveis pela divisão histórica do trabalho.

O enfoque culturalista remete ao conceito de "condicionamento cultural" da antropóloga Benedict (2006), segundo o qual cada cultura seleciona, dentro da gama de possibilidades humanas, algumas características aceitas como adequadas para seus membros, sendo as culturas, portanto, as principais reguladoras da personalidade.

A hipótese mais simples e difundida neste enfoque é a de que a socialização primária para papéis masculinos e femininos seria a responsável pelas diferenças psicológicas entre homens e mulheres em termos de predisposição e competência para o cuidado. Meninas seriam encorajadas desde cedo a brincar com bonecas e casinhas, brincadeiras que são desencorajadas e até punidas entre meninos entre outros motivos, por receio de futuro homossexualismo. A socialização masculina encorajaria força, valentia, contenção emocional, exploração do mundo, enquanto a feminina encorajaria cooperação, sensibilidade, solidariedade e atividades espacialmente mais restritas (Lyra \& Cols, 2005).

No limite, esse modelo peca por um excesso de simplismo. Ele ignora a condição da criança como agente ativo de seu desenvolvimento, como indivíduo que faz escolhas entre as opções oferecidas pelo seu ambiente, condição que hoje é reconhecida como um dos pilares de qualquer teoria de desenvolvimento. No entanto, há outras formas mais elaboradas de atribuir exclusivamente à influência do ambiente social ou à transmissão cultural, as diferenças entre os gêneros em termos de propensão ao cuidado. 
Para exemplificar, podemos citar a identificação com modelos, um dos processos básicos de constituição de identidade de gênero e de transmissão cultural. Identificando-se com figuras femininas relevantes de seu entorno social, a menina tenderia a assimilar seus valores, suas práticas e seus papéis, constituindo-se como pertencente ao gênero feminino, perpetuando estes valores, práticas e papéis, o mesmo processo ocorreria com os meninos e seus respectivos modelos. Berger e Berger (1977) enfatizam particularmente o papel da linguagem nesses processos de transmissão: é por meio da linguagem que a criança, em sua experiência cotidiana com parceiros sociais, é envolvida em aspectos macrossociais que se situam além do microcosmo das experiências imediatas, e toma conhecimento do mundo externo e dos papéis sociais nele prescritos.

Cabe lembrar que a identificação com modelos não é mecânica e determinada: não necessariamente a menina se identifica com a mãe (poderia, por exemplo, identificar-se com uma tia que é uma executiva bem sucedida e sem filhos) ou o menino com o pai (ao invés, poderia identificar-se com um artista que oferece modelo bem diferente daquele de sua família de origem), pode haver inclusive uma identificação cruzada em termos de gênero (o menino com a mãe e a menina com o pai ou com outras figuras femininas/ masculinas).

Em geral, no entanto, a identificação tenderia a ocorrer de maneira a maximizar a possibilidade de transmissão e permanência dos valores, atitudes e práticas dominantes em uma cultura particular. Mudanças culturais frequentemente são lentas e, muitas vezes, um preço alto é pago por aqueles que as introduzem e/ou as defendem.

Outra observação interessante no contexto da atribuição de papéis relacionados ao cuidar e das formas de sua perpetuação cultural é a de que mães que solicitam a ajuda dos filhos para tarefas domésticas tendem a distribui-las segundo a estereotipia de gênero prevalente em sua cultura: meninas são chamadas para cuidar dos irmãos menores, para limpar a casa e ajudar na cozinha, enquanto os meninos recebem mais incumbências "de rua", do espaço público, do exterior, como fazer pequenas compras, levar recados ou encomendas (Damatta, 2000).

Ao reproduzir essas estereotipias, as mães dariam mais oportunidade de prática de cuidado às meninas? $\mathrm{O}$ que refletiria em aumento de sua competência nessa área e retroalimentaria a tendência a solicitar a ajuda das meninas para essas tarefas. Ou será que as mães tendem, por identificação de gênero, a confiar mais 
nas meninas do que nos meninos para a realização dessas tarefas, considerando-as, em princípio, mais competentes?

Ambos os fatores podem estar presentes e atuar de forma interativa: se atribui mais competência à menina nestas tarefas, a mãe a constitui como mais competente e lhe dá assim a oportunidade de efetivamente tornar-se tal. Por outro lado, retomando o enfoque biológico e a suposição de que as mulheres têm uma propensão e/ou uma preparação diferenciais para o cuidado, pode ser que as mães identifiquem esta competência diferencial na prática e sejam orientadas por ela. Novamente, a interpretação deste tipo de dado não é simples, e envolve uma interação complexa entre características de gênero e experiências culturais.

Outra fonte de modelação cultural que tem sido apontada é a escola. Cavalcanti (2005) comenta que, embora atualmente as mulheres ultrapassem os homens em nível de instrução, em 2002, constituíam 53,5\% das concluintes do ensino fundamental, 58,5\% do ensino médio e $61,4 \%$ do ensino superior, segundo relatório da Organização para a Cooperação e o Desenvolvimento Econômico (conforme citado por Cavalcanti), a discriminação de gênero continua presente nas propostas escolares e no material didático, que vincula homens ao trabalho e a relações externas e mulheres à vida doméstica e familiar. Por exemplo, as professoras, em sua maioria do sexo feminino, refletem em seu trabalho os preconceitos e valores que permearam sua própria educação, contribuindo para perpetuá-los. A diferenciação de objetivos entre a educação masculina e feminina está bem marcada nas propostas curriculares do século XIX, com a formação em escolas separadas, além de atividades extracurriculares direcionadas para a construção da mãe/esposa (Cavalcanti, 1996).

Uma perspectiva interessante e pouco usual de análise destas questões é sugerida por Lyra e cols. (2005): raramente se considera que este modelo de socialização priva os meninos de experiências potencialmente importantes em termos afetivos e de competências sociais. É como se não fosse permitido aos homens se tornarem cuidadores. Note-se que nas últimas décadas, pelo menos em camadas socioeconômicas mais privilegiadas, esta distinção parece tender a se reduzir: em correspondência à crescente participação feminina, em condições de igualdade ou quase igualdade, no mercado de trabalho formal, jovens casais parecem praticar cada vez mais uma divisão de tempo também mais igualitária no que se refere ao âmbito doméstico e especialmente ao cuidado dos filhos, incluindo- 
se aí a presença e participação de pais na situação de parto. É possível supor que esta tendência, se consolidada, configure mudança cultural importante, que poderia se propagar para outras camadas da sociedade (Lyra \& Cols, 2005).

Em médio e longo prazo, esse poderia ser um teste interessante em termos de comparação entre os dois enfoques abordados aqui. Mas, antes disso, será possível (e/ou útil) de alguma forma identificar complementaridades nestes dois enfoques ou mesmo integrá-los?

Um desafio que se coloca aos enfoques radicalmente culturalistas é compreender a recorrência de determinadas formas culturais ao longo da história em sociedades independentes e em momentos diversos do tempo. É como se estas formas refletissem uma estrutura profunda da sociabilidade e do modo de vida social dos seres humanos dito de outra forma, da "natureza humana", um conceito generalizadamente rejeitado por estes enfoques. Lévi-Strauss (2003), marco fundamental da Antropologia na discussão desta questão, aborda-a em relação ao tabu do incesto, que considera como o único universal humano: a única entre as regras sociais que reúne os atributos de duas ordens exclusivas, as dos atributos da ordem da natureza e os da ordem da cultura, pois, sendo norma, é ao mesmo tempo universal. Ao final do capítulo em que se desenvolve essa discussão, o autor expressa o estado de espírito dos cientistas diante deste mistério: os sociólogos, conclui, são quase unânimes em sua timidez diante desse problema.

Sperber (1985) utiliza a expressão "universais culturais" para se referir a diversas outras formas culturais que apresentam esse mesmo desafio, entre as quais ritos funerários, danças, mitos, rituais religiosos e tradições culinárias. A universalidade, evidentemente, não está no conteúdo particular que essas formas culturais assumem em cada caso, o que justamente constitui identidades culturais diversas, e sim na ocorrência recorrente dessas formas, ou estruturas, em contextos culturais diversos e independentes.

Nossa questão é: será que na divisão de trabalho por gênero há uma tendência recorrente à assunção pelas mulheres e/ou a atribuição a elas, mais do que aos homens, do papel de cuidadora? É o que parece pelas revisões disponíveis na literatura, com variações culturais sugestivas. A Antropologia relata que há culturas em que o papel de cuidadora da mulher em relação aos filhos é limitado à primeira infância, no caso de filhos do sexo masculino: por volta dos cinco anos, os meninos passam à guarda do pai ou de um tio, que os socializará segundo os papéis 
masculinos prescritos socialmente desta forma também reproduzindo a divisão tradicional de trabalho por gênero, ou seja, criando um rapaz que não cuidará de crianças até cinco anos e nem de meninas em qualquer idade.

Uma das maneiras de interpretar a prevalência de mulheres no papel de cuidadoras é em termos da posição social subordinada das mulheres, fenômeno recorrente pelo menos desde as sociedades agrícolas e pastoris da Antiguidade. Pode-se pensar que, devido a seu status menor na hierarquia social, às mulheres eram atribuídas tarefas menos valorizadas socialmente por não serem produtoras de valor de troca. $\mathrm{Ou}$, reciprocamente, por não produzirem valor de troca e por serem desempenhadas por mulheres, já socialmente discriminadas, estas tarefas teriam tido seu valor social reduzido, completando uma circularidade de significados culturais.

Ainda assim, não é fácil compreender porque as mulheres continuam a assumir majoritariamente as tarefas básicas de cuidado, mesmo quando participam da produção de bens de troca, o que nas classes menos favorecidas é uma constante desde sempre na história humana, em maior ou menor grau. Nas sociedades contemporâneas, muitas mulheres de classe média e alta trabalham em regime integral e responsabilizam-se pelos filhos e pela administração doméstica. No entanto, direta ou indiretamente delegam o cuidado dos filhos e da casa a uma outra pessoa, seja ela familiar, empregada ou educadora de creche, tipicamente também mulheres.

Pode-se perguntar: será que as mulheres não confiam nos homens para essas tarefas? Esta hipótese seria compatível com a ideia de que as mulheres são melhor dotadas e mais motivadas do que os homens para o cuidado, devido às pressões seletivas decorrentes de seu alto investimento parental. Esta melhor dotação justificaria a prevalência cultural de mulheres cuidadoras: arranjos culturais também precisam ser eficientes e, para isso, em alguma medida precisam compatibilizar-se com as condições físicas e psicológicas dos agentes sociais.

Neste contexto, é mais uma vez interessante recorrer a Mead (2000), assim como indicado acima, Mead sustenta que os traços selecionados por cada cultura não têm base biológica em termos de sexo, ou seja, não são geneticamente masculinos ou femininos, o que poderia ser inato, em sua concepção, são as diferenças individuais de temperamento, que representam a gama de possibilidades características da espécie humana e que estão presentes em ambos os sexos em 
todas as populações humanas, ainda que com prevalência variável. Sobre esta distribuição de características de temperamento é que atuaria a pressão cultural, a qual os indivíduos se ajustariam com maior ou menor facilidade dependendo de suas características "inatas".

Assim, uma interpretação biológica das diferenças culturais documentadas por ela poderia ser a de que, em uma cultura "masculinizada", as pressões culturais resultariam em maior incidência na população de mulheres com traços "masculinos", que são socialmente mais valorizadas e, portanto, têm mais acesso ao casamento e à procriação. Por outro lado, em culturas que apresentam os traços "femininos" dos homens teriam espaço social para se manifestar e, consequentemente, ocorreriam com maior frequência na população. Esta é uma das formas possíveis de compatibilizar ou articular os enfoques biológicos e culturalistas, conforme defendido pela própria Mead (2000), que critica a perda de diálogo da Antropologia com as ciências biológicas.

Contudo, nenhum destes argumentos justifica a desvalorização social do papel de cuidador. Decorreria ela de sua associação com o sexo feminino e seu lugar social? Colocar a questão em termos de oposição, tais como: o cuidado é desvalorizado porque é um papel historicamente atribuído à mulher, ou a mulher é desvalorizada porque historicamente tendeu a assumir esse papel parece correr o risco de uma simplificação excessiva.

Para aprofundar esta questão, seria preciso compreender melhor quando, onde e por que o cuidado principalmente no sentido de cuidado interpessoal, já que se pode atribuir ao homem uma outra forma de cuidado como provedor perde valor social, se isso está ou não associado à desvalorização social da mulher e/ou à sua exclusão do trabalho produtivo (lembrando a relatividade dessa exclusão, já que, conforme foi argumentado antes, mulheres sempre participaram em alguma medida do trabalho produtivo) e com isso à sua dependência do sustento masculino. 


\section{4. \\ Gênero, geração e classes sociais}

Neste ponto, voltamos às pesquisas realizadas por Lins de Barros (2008; 2009) acerca do debate sobre a família contemporânea. A autora estuda famílias de camadas médias urbanas, procurando tratar das relações entre as gerações e as relações de gênero dentro do contexto das relações familiares. O interessante em seus trabalhos é a proposta de ampliar as discussões sobre redes sociais, solidariedade familiar, autonomia e independência na família nas diferentes gerações, a responsabilidade e sentido de obrigatoriedade em relação aos mais velhos e também aos mais jovens.

Para Lins de Barros (2008), existe uma tensão entre as mudanças e permanências entre diferentes gerações, pois ao mesmo tempo em que, atualmente, as transformações da sociedade ocorrem de maneira muito rápida, as informações são praticamente fluidas; há um sentimento de continuidade, de valorização dos ideais da família. Utilizando suas palavras, "uma ideia de continuidade e até mesmo de uma sacralização da continuidade e do passado compõe o conjunto de fatores para a compreensão das relações sociais na sociedade moderno-contemporânea" (Lins de Barros, 2008, p. 2). A estudiosa trata, então, das relações intergeracionais e da construção da identidade de geração.

Ainda segundo estudo realizado pela autora em questão para investigar as diferenças e semelhanças entre gerações e de que forma tratam das relações entre as gerações femininas na família, constatou que para as mulheres da geração intermediária, existe uma tensão entre individualizar-se e ser incorporada ao grupo familiar (Lins de Barros, 2008, p. 5). Estudos demonstram modelo assimétrico de gênero nas relações familiares, no ambiente de trabalho, no meio político. Barros cita Gilberto Velho para afirmar que os ideias de autonomia, liberdade e independência nada têm a ver com concepções evolutivas de valores individualistas, mas sim em compreender a heterogeneidade cultural de nossa sociedade.

Lins de Barros (2008) conclui ao fim desta pesquisa que uma visão comum às gerações de mulheres de camadas médias, é a autonomia nas decisões relativas às suas vidas e a importância que creditam a não precisar se submeter a ninguém. 
Acrescenta ainda que não é apenas o fator geracional que concorre para a heterogeneidade dos valores individuais, mas sua profissionalização, educação, conjugalidade, maternidade e solidariedade intergeracional.

Em outro estudo realizado por Lins de Barros (2009), apresenta uma comparação entre as representações de gênero em diferentes gerações de famílias de camadas médias e populares do Rio de Janeiro, priorizando as percepções do lugar social da mulher no contexto das transformações da sociedade brasileira. A autora busca conhecer as representações e práticas das mulheres de três gerações distintas em torno da família, religião e profissionalização feminina (Lins de Barros, 2009).

O estudo reitera que no segmento das mulheres economicamente ativas e com maior nível de instrução, as representações de gênero tradicionais tendem a ser mais questionadas. Por outro lado, demonstra o crescimento significativo da participação das mulheres pobres no cenário econômico. Segundo constatação de Lins de Barros (2009), este seria um fenômeno novo, visto que nas décadas anteriores este segmento representava percentagens de representação inferiores às mulheres das camadas médias e altas da sociedade brasileira. Deste modo, com baixos níveis de escolaridade e poucos recursos para o cuidado dos filhos, estas mulheres apresentam dificuldades quanto ao exercício profissional, inserindo-se em atividades de baixo prestígio social.

Verificou-se, ainda, no decorrer desta pesquisa que, apesar da participação destas mulheres ser relevante para a manutenção econômica do grupo doméstico, existe um pensamento hierárquico no sistema de distribuição de autoridade na família, cabendo aos homens o sustento da casa e às mulheres, o cuidado dos filhos e afazeres domésticos. Resultado que fortalece o que temos observado no decorrer do presente estudo.

Ainda pela perspectiva de Lins de Barros (2013), para mulheres que nasceram entre o final da década de 40 e o fim da década seguinte, há um entorno cultural de mudanças na ordem dos valores e das práticas da vida cotidiana que nos permite estabelecer um marco geracional particularmente importante para as mulheres das camadas médias (Lins de Barros, 2013). Deste modo, as mulheres desta faixa etária experimentaram transformações sociais que envolvem diferentes campos da vida como a sexualidade, a família, as relações entre homens e mulheres e entre gerações na vida familiar, no trabalho e em diferentes esferas de sociabilidade. Vivenciaram 
também mudanças ocorridas na sociedade, com a reestruturação do perfil do trabalhador, com a entrada crescente das mulheres no mercado de trabalho, a profissionalização de mulheres de segmentos médios urbanos, o controle de natalidade e, portanto, a diminuição do número de filhos especificamente nestes segmentos sociais, além do aumento da ocorrência de divórcio, levando à reconfiguração da família e da conjugalidade. Assim, compreendendo a importância das mudanças nas formas de pensar e agir e na construção das subjetividades dos indivíduos, Lins de Barros (2013) busca compreender as diferenças e aproximações entre as trajetórias das três gerações de mulheres e as perspectivas distintas de cada geração sobre sua própria vida e sobre as relações familiares.

Em trabalho anterior, Lins de Barros (1987) apontava que as avós, acompanhando as transformações relativas à mulher de camadas médias, encorajavam as filhas a se profissionalizarem e a conquistarem independência financeira. Todavia, havia um limite ao incentivo à autonomia e à independência que se apresentava quando a função à maternidade era colocada em questão. É no momento marcado pelas grandes transformações nas relações conjugais e pela redefinição e questionamento do valor da própria família que esta solidariedade feminina intergeracional faz sentido para as avós entrevistadas. Quando os netos são pequenos é com as próprias filhas que as avós estabelecem as relações mais intensas no quotidiano. A solidariedade feminina no cuidado com crianças mostra a ausência ou pouca participação dos homens no trabalho doméstico. "A força feminina no mundo doméstico ganha uma dimensão particular no momento em que as transformações ocorridas na família conjugal, nestes segmentos sociais de camadas médias, desestabilizam um sistema de divisão sexual de trabalho" (Lins de Barros, 1987, p. 72).

Para a geração mais velha, o casamento impediu o prosseguimento dos projetos de trabalho e de estudos. Casar foi, para grande parte das mulheres, uma interrupção do trabalho fora de casa e dos estudos e elas acabaram assumindo a tarefa do cuidado, cabendo a elas o trabalho doméstico não apenas material, mas simbólico (Lins de Barros, 1987). Este lhes garante o poder da transmissão de legados, mesmo que estejam fundados na divisão sexual tradicional do trabalho e na assimetria de gênero. A transmissão de valores na educação dos filhos é sua atribuição, assim como o é a responsabilidade pela manutenção do vínculo afetivo 
com o marido, uma vez que "estariam especialmente vocacionadas para as emoções, a domesticidade, as relações familiares" (Torres, 2000, p. 154).

O momento histórico é outro, assim como é outro o lugar social em que se encontram na família e na vida pública e é com nova perspectiva que estas mulheres estão tratando os dilemas próprios de sua geração, mas a contrariedade e o enfrentamento dos problemas e conflitos fazem parte também de suas vidas, reproduzindo, muitas vezes, em novas relações afetivas as fórmulas e padrões tradicionais de relações de gênero.

Diante do exposto acima, observamos que, apesar de haver mudanças significativas em relação à distribuição de tarefas de cuidado entre homens e mulheres dentro do âmbito familiar, esta ainda não acontece de maneira igualitária. Vimos que a participação no mercado de trabalho, níveis mais elevados de instrução e o pertencimento a gerações mais jovens correlacionam-se positivamente com o ideário mais igualitarista. Faz-se necessário percebermos que as diferenças entre homens e mulheres não são um processo natural, elas são socialmente construídas pela sociedade, sendo assim, um produto histórico, variável no tempo e no espaço. Deste modo é preciso que haja reorganização da divisão do trabalho, a fim de proporcionar um maior compartilhamento das atividades, bem como a construção de políticas públicas que possibilitem às mulheres as mesmas oportunidades de trabalho existente aos homens para se construir relações mais horizontais entre os gêneros que possam ser reproduzidas e mantidas no âmbito do privado e do público. 


\section{4 \\ Considerações Finais}

As categorias 'família' e 'cuidado' estão intimamente ligadas, visto que as famílias se configuram como as principais responsáveis pelo cuidado e proteção dos seus membros. Os comportamentos familiares associados aos modos de cuidado são variáveis, já que cada família constrói sua própria dinâmica; influenciada por contextos históricos, ideológicos e psicológicos.

No decorrer de nosso estudo, analisamos de que maneira a família brasileira foi se constituindo historicamente e como o cuidado passou a fazer parte deste contexto, abordando as variadas conceituações de família existentes no período do Brasil- Colônia até os dias atuais. Observamos que desde os primórdios da existência humana, o cuidado estava presente e foi se especializando ao longo dos anos, tanto quanto as atividades humanas. Notamos que historiadores e antropólogos consideram que a proteção materna instintiva foi a primeira forma de manifestação do cuidado humano.

Assim, a presente pesquisa possibilitou explorarmos a produção já realizada a respeito do assunto, identificando elementos que aparecem com frequência dentro do contexto do cuidado familial.

Segundo os autores estudados, cuidado compreende atenção, preocupação e interesse no outro. Implica, portanto, respeitar o próximo. Outro elemento que aparece em alguns trabalhos é a preservação pois, como vimos, é através das relações interpessoais e da relação do sujeito com o mundo ao seu redor, que a pessoa irá se construindo e dando continuidade a tudo o que existe. Alguns estudiosos, ainda, entendem que cuidado envolve autopreservação, pois defendem que somente após estarmos cuidados é que estaremos aptos a cuidar do outro.

Além disso, destacamos as necessidades físicas, como o abrigo, o alimento e a segurança e, as necessidades afetivas, que incluem sentimento de pertencimento, amparo e proteção como elementos também integrantes do cuidado.

O cuidado apresenta também uma dimensão cultural e, dependendo da sociedade em que a família está inserida, seu modo de entender cuidado poderá se apresentar de formas diferentes. Ademais, pudemos observar que muitas vezes é 
necessária uma reorganização da dinâmica familiar quando uma nova situação se apresenta, como por exemplo, a separação do casal, a saída da mulher para a entrada no mercado de trabalho formal ou o envelhecimento de um membro da família, em que a pessoa que cuidava passa a ser cuidada.

Um aspecto relevante percebido ao longo do estudo foi a divisão sexual do trabalho dentro do âmbito familiar. Observamos que, apesar das significativas transformações ocorridas no Brasil no decorrer da história, ainda percebemos desigualdades nas distribuições de tarefas, tidas como predominantemente femininas e funções vistas como naturalmente masculinas. Assim, ainda hoje percebemos que funções de cuidado são atribuídas predominantemente às mulheres e, aos homens cabe o sustento do lar. Alguns estudos apontam que existem afazeres inexplorados pelos homens, como lavar roupas e limpar a casa e que, quando o homem exerce funções de cuidado, estas não estão diretamente vinculadas ao ambiente familiar, como por exemplo pegar e buscar os filhos na escola.

Outro fator visto como importante e relacionado às maneiras de perceber o cuidado são as classes sociais a que a família pertence. Estudos explorados no decorrer da presente pesquisa demonstram que no segmento das mulheres economicamente ativas e com maior nível de instrução, as representações de gênero tradicionais tendem a ser mais questionadas, porém ainda assim, estas mulheres somente serão valorizadas se conseguirem conciliar o trabalho formal com os cuidados aos membros da família. Esta situação não se apresenta da mesma maneira para os homens, pois a estes cabe basicamente o sustento do lar.

Uma dificuldade observada na pesquisa, e que desde o início foi o motor que nos impulsionou a buscar o máximo de fundamentos em relação ao cuidado familial sob uma perspectiva epistemológica, foi a falta de materiais que abordassem o cuidado como tal e não como prática. Apesar disso, esperamos que esta pesquisa tenha contribuído para refletirmos acerca do cuidado familial como um possível conceito a ser desenvolvido com base nos elementos levantados. Todavia, esta é uma questão a ser pensada para um próximo estudo. 


\section{Referências bibliográficas}

ABREU, C. N. Teoria do apego-fundamentos, pesquisas e implicações clínicas. São Paulo: Casa do Psicólogo, 2005.

ALMEIDA, M. A. Família e trabalho: o casal e a empresa familiar. Salvador: FIB, 2005.

ARAUJO, C; SCALON, C. Percepções e atitudes de mulheres e homens sobre a conciliação entre família e trabalho pago no Brasil. In: ARAUJO, C; SCALON, C. (Orgs.). Gênero, Família e Trabalho no Brasil. Rio de Janeiro: FGV/FAPERJ, 2003.

ARIÉS, P.; DUBY, G. História da Vida Privada. São Paulo: Cia das Letras, v.3, 1991.

ARIÈS, P. História Social da Criança e da Família. Rio de Janeiro: Editora Guanabara, 1978.

BENEDICT, R. Patterns of culture. New York: Houghton Mifflin, 2006.

BERGER, P. L.; BERGUER, B. O que é uma instituição social? In: FORACCHI, M. M.; MARTINS, J. S. (Orgs.). Sociologia e sociedade. Rio de Janeiro: Livros Técnicos e Científicos, 1977.

BILAC, E. D. Sobre as transformações nas estruturas familiares no Brasil. Notas muito preliminares. In: RIBEIRO, I.; RIBEIRO, A. C. T. (Orgs.). Famílias em Processos Contemporâneos: inovações culturais na sociedade brasileira, São Paulo, Edições Loyola, 1995.

BOFF, L. Saber Cuidar: ética do humano - compaixão pela terra. Rio de Janeiro: Vozes, 2011.

O cuidado essencial: princípio de um novo ethos. Inclusão Social, Brasília, v. 1, n. 1, 2005.

BOMFIM, A. C.; BASTOS, A. C.; CARVALHO, A. M. A. A família em situações disruptivas provocadas por hospitalização. Revista Brasileira de Crescimento e Desenvolvimento Humano, São Paulo, 2007. 
BOWLBY, J. Apego e perda. São Paulo: Martins Fontes, v. 1, 1990.

BRUSCHINI, C. Teoria crítica da família. In: AZEVEDO. M. A.; GUERRA, V. N. (Orgs.). Infância e violência doméstica: fronteiras do conhecimento. São Paulo: Cortez, 1993.

BUENO, E. Capitães do Brasil: A saga dos primeiros colonizadores. Rio de Janeiro: Objetiva, 1999.

CANDIDO, A. The Brazilian Family. In: SMITH, T. L.; MARCHANT, A. (Orgs.). Brazil: portrait of half a continent. Nova York, The Dryden Press, 1951.

CARVALHO, A. M. A. et al. Mulheres e cuidado: bases psicobiológicas ou arbitrariedade cultural? Paidéia, Ribeirão Preto, v.18, n. 41, 2008.

CASTELLS, M. O fim do patriarcalismo: movimentos sociais, família e sexualidade na era da informação. In: CASTELLS, M. O Poder da Identidade. v. 2, São Paulo: Paz e Terra, 2000.

CASTRO, M. G.; MIRANDA, M. B. S.; ALMEIDA, N. O. Juventude, gênero, família e sexualidade: combinando tradição e modernidade. In: BORGES, A.; CASTRO, M. G. Família, gênero, gerações: desafios para as políticas sociais. São Paulo: Paulina, 2007.

CAVALCANTI, V. R. S. Vestígios do tempo: Memórias de mulheres católicas (1929-1942). São Paulo, 1996. Dissertação (Mestrado) - Pontifícia Universidade Católica de São Paulo. (Dissertação de mestrado não publicada).

A contramaré da exclusão, pobreza e trabalho: visibilidade da condição feminina no Brasil. In: PETRINI, J. C.; CAVALCANTI, V. R. S. (Orgs.). Família, sociedade e subjetividades: uma perspectiva multidisciplinar. Petrópolis: Vozes, 2005.

CORRÊA, M. Repensando a família patriarcal brasileira. In: CORRÊA, M. (Org.). Colcha de retalhos: estudos sobre a família no Brasil. São Paulo: Brasiliense, 1982.

COSTA, J. F. Ordem médica e norma familiar. Rio de Janeiro: Graal, 1989.

COSTA, R. G. Reprodução e gênero: paternidades, masculinidades e teorias da concepção. Revista Estudos Feministas, Florianópolis, v. 10, n.2, 2002.

DA MATTA, R. A casa e a rua: espaço, cidadania, mulher e morte no Brasil. Rio de Janeiro: Rocco, 2000. 
DA MATTA, R. Relativizando: uma introdução à antropologia social. Rio de Janeiro: Editora Rocco, 1987.

DELCOR, N. S. et al. Condições de trabalho e saúde dos professores da rede particular de ensino de Vitória da Conquista, Bahia, Brasil. Cadernos de Saúde Pública, Rio de Janeiro, v. 20, n. 1, p. 187-196, 2004.

DEL PRIORE, M. D. (Org.). História das Mulheres no Brasil. São Paulo: Contexto, 2006. . São Paulo: Contexto, 2001.

DE MASI, D. Criatividade e grupos criativos. Rio de Janeiro: Sextante: 2003.

DONAHUE, M. P. História de la enfermeria. Barcelona: Doyma, 1985.

ELSEN, I. Cuidado familial: uma proposta inicial de sistematização conceitual. In: ELSEN, I.; MARCON, S. S, SANTOS, M. R. (Orgs). O viver em família e sua interface com a saúde e a doença. Maringá: Eduem; 2002. p. 11-24.

ENGELS, F. A origem da família, da propriedade privada e do estado. Rio de Janeiro: Civilização Brasileira, 1981.

FOUCAULT, M. História da sexualidade: o cuidado de si. Rio de Janeiro: Graal, 1985.

Ética, sexualidade, política. Col. Ditos e Escritos. Rio de Janeiro: Forense Universitária, 2006.

FREYRE, G. Casa Grande \& Senzala: formação da família brasileira sob o regime da economia patriarcal. Rio de Janeiro: José Olympio, 1981.

GONÇALVES, H. S. Infância e violência no Brasil. Rio de Janeiro: NAU Editora, 2003.

HEIDEGGER, M. O Ser e o Tempo. Editora Vozes, cap. 6. Rio de Janeiro, 2005.

HOLANDA, Sérgio Buarque de. Raízes do Brasil. São Paulo: Companhia das Letras, 1995.

HOUAISS, Antônio. Dicionário Houaiss da Língua Portuguesa. Rio de Janeiro: Ed. Objetiva, 2001.

JABLONSKI, B. O cotidiano do casamento contemporâneo: a difícil e conflitiva divisão de tarefas e responsabilidades entre homens e mulheres. In: FÉRES- 
CARNEIRO, T. (Org.). Família e casal: saúde, trabalho e modos de vinculação. São Paulo: Casa do Psicólogo, 2007.

LÉVI-STRAUSS, C. As estruturas elementares do parentesco. Petrópolis: Vozes, 2003.

LEWIS, J. O homem e a evolução. Rio de Janeiro: Paz e Terra, 1968.

LINS de BARROS, M. M. L. Autoridade e afeto: avós, filhos e netos na família brasileira. Rio de janeiro: Zahar, 1987.

Gênero, geração e classe: uma discussão sobre as mulheres das camadas médias e populares do Rio de Janeiro. Rio de Janeiro: Universidade Federal do Rio de Janeiro, 2008.

Três gerações femininas em famílias de camadas médias: trajetórias de vida e o projeto de autonomização. In: VELHO, G.; DUARTE, L. F. D. (Orgs.). Gerações, família, sexualidade. Rio de Janeiro: 7Letras, 2009.

Experiências femininas na maturidade. Revista Feminismos, v. 1, n.3. Ufba: Universidade Federal da Bahia, 2013.

LORDELO, E. R.; CARVAlHO, A. M. A. Comportamento de cuidado entre crianças: uma revisão. Brasília: Psicologia- Teoria e Pesquisa, 5, 1-19, 1989.

LYRA, J.; LIMA, L. S.; TARGINO, D. C.; SANTOS, B. Homens e cuidado: uma outra família? In: ACOSTA, A. R.; VITALE, M. A. F. Famílias: redes, laços e políticas públicas. São Paulo: Cortez, 2005.

MACEDO, R. M. A família diante das dificuldades escolares dos filhos. In: BOSSA, N.; OLIVEIRA, V. B. (Orgs.). Avaliação Psicopedagógica da criança de 0 à 6 anos. Petrópolis: Vozes, 1994.

MARANHÃO, D. G. O Cuidado como Elo entre Saúde e Educação. Cadernos de Pesquisa, n.111, São Paulo, 2000.

MEAD, M. Antropologia, la ciência del hombre. Disponível em: $<$ https://docs.google.com/viewer?a=v\&pid=sites\&srcid=ZGVmYXVsdGRvbWFp bnx0ZXh0b3NkZWFudHJvcG9sb2dpYWZpbG9zb2ZpY2F8Z3g6NGJiMWY5Y WIxMjQ3MGZjMg>. Acesso em: 20 jun. 2017.

MIOTO, R. C. T. Família e serviço social. Revista Serviço Social \& Sociedade, São Paulo, v. 17, n. 55, 1997.

Família e saúde mental: contribuições para reflexão sobre processos familiares. Revista Katálysis. Santa Catarina, 1998. 
MORGADO, R. Família(s) e Relações de Gênero. In: Praia Vermelha: estudos de política e teoria social. Rio de Janeiro, UFRJ, n. 5, p. 190-215, $2^{\circ}$ semestre de 2001.

MORRIS, D. Você: um estudo objetivo do comportamento humano. São Paulo: Círculo do Livro, 1977.

OLIVEIRA, A. C. Abuso sexual intrafamiliar de crianças e ruptura do segredo: consequências para as famílias. Rio de Janeiro: 2011. Tese (Doutorado em Serviço Social) - Departamento de Serviço Social, Pontifícia Universidade Católica do Rio de Janeiro - PUC-Rio.

QUINTANEIRO, T. Retratos de mulher: o cotidiano feminino no Brasil sob o olhar de viageiros do século XIX. Petrópolis: Vozes, 1995.

RIBEIRO, D. O Povo Brasileiro: a Formação e o Sentido do Brasil. Rio de Janeiro: Cia das Letras, 1995.

RIDENTI, S. G. V. A desigualdade de gênero nas relações parentais: o exemplo das custódias dos fillhos. In: ARILHA, M; RIDENTI, S. G. V.; MEDRADO, B. (Org.). Homens e masculinidades: outras palavras. São Paulo: ECOS, 1998.

ROCHA-COUTINHO, M. L. Quando o executivo é uma "dama": a mulher, a carreira e as relações familiares. In: FÉRES-CARNEIRO, T. (Org.). Família e casal: arranjos e demandas contemporâneas. Rio de janeiro: Loyola, 2003.

RODRIGUES, M. M. P. Evolução do investimento parental em primatas: o caso do Homo sapiens. In: SOUZA, M. F. Q.; RODRIGUES, M. M. P. (Orgs.). Psicologia: reflexões (im) pertinentes. São Paulo: Casa do Psicólogo, 1998.

SAMARA, E. M. O que mudou na família brasileira? (da colônia à atualidade). Psicologia USP, v. 13, n .2, 2002.

As mulheres, o poder e a família. São Paulo: Marco Zero/ Secretaria de Estado da Cultura de São Paulo, 1989.

A Família Brasileira. São Paulo: Brasiliense, 1983.

SARAIVA, E. S. Paternidade e masculinidade: tradição, herança e reinvenção. Porto Alegre: 1998. Dissertação (Mestrado) - UFRGS/FACED,

SILVA, G.; NADER, M. B.; FRANCO, S. História, mulher e poder. Vitória: EdUFES, 2006.

SOARES, M. P. Comportamento de cuidado: Quando as crianças com necessidades especiais são cuidadas por irmãos em ambiente familiar. Salvador: 2005. Dissertação (Mestrado) - Universidade Católica de Salvador. 
SPERBER, D. Contra certos a priori antropológicos. In: MORIN, E.; PIATTELLIPALMARINI, M. (Orgs.). A unidade do homem. São Paulo: Cultrix, 1985.

SPINK, M. J. P. Experiences of first pregnancy and use of antenatal services in São Paulo, Brazil. London: 1982. Dissertation - University of London.

STAMM, M; MIOTO, M. Família e cuidado: uma leitura para além do óbvio. Ciência, cuidado e saúde, Maringá, v. 2, n. 2, 2003.

SZYMANSKY, H. Teorias e "teorias" de famílias. In: CARVALHO et al. A família contemporânea em debate. São Paulo: Record, 2005.

TORRES, A. A individualização no feminino, o casamento e o amor. In: PEIXOTO, C. (Org.). Família e individualização. Rio de Janeiro: FGV Editora, 2000.

Casamento: tempos, centramento, gerações e gênero. Bahia: Caderno CRH, 17, P. 405-429, 2004.

VAINFAIS, R. Trópico dos Pecados. Rio de Janeiro: Nova Fronteira, 1989.

WINNICOTT, D. W. The Theory of the Parent-Infant Relationship. International Journal of Psycho-Analysis, 1960.

A criança e o seu mundo. Rio de Janeiro: Guanabara Koogan, 1982.

Conversando com os pais. São Paulo: Martins Fontes, 1999.

Tudo começa em casa. São Paulo: Martins Fontes, 1989.

ZIMERMAN, D. E. Fundamentos Psicanalíticos: teoria, técnica e clínica - uma abordagem didática. Porto Alegre: Artmed, 1999. 